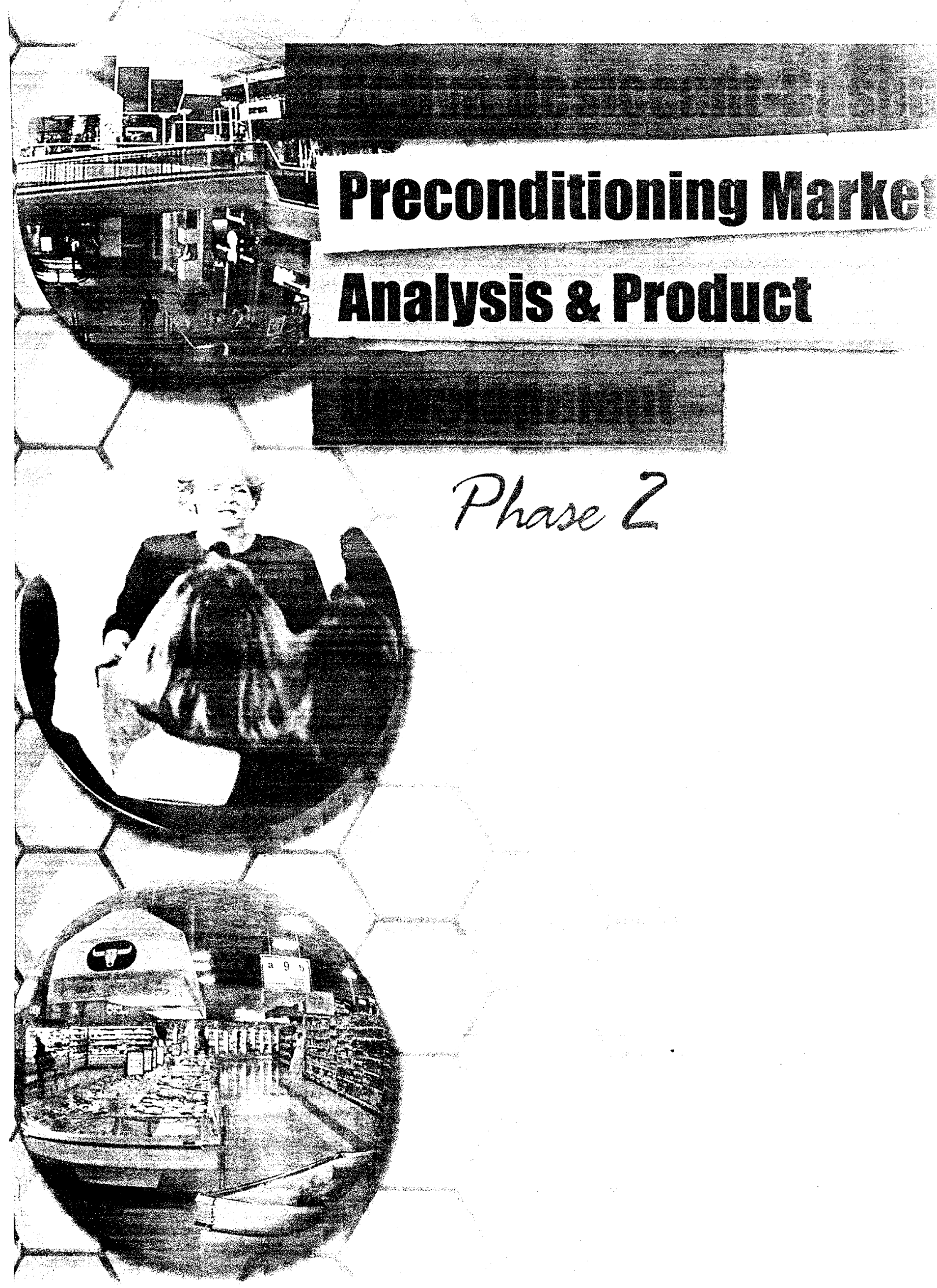





\title{
ACTIVE DESICCANT-BASED PRECONDITIONING MARKET ANALYSIS AND PRODUCT DEVELOPMENT
}

\author{
J. Fischer \\ SEMCO, Inc.
}

June 2000

Prepared by

SEMCO, Inc.

$$
\text { for }
$$

OAK RIDGE NATIONAL LABORATORY

Oak Ridge, Tennessee 37831-6285

managed by

UT-Battelle, LLC

for the

U.S. Department of Energy

under Contract No. DE-AC05-00OR22725 


\section{CONTENTS}

LIST OF FIGURES $\ldots \ldots \ldots \ldots \ldots \ldots \ldots \ldots \ldots \ldots \ldots \ldots \ldots \ldots \ldots \ldots \ldots \ldots \ldots \ldots$

LIST OF TABLES $\ldots \ldots \ldots \ldots \ldots \ldots \ldots \ldots \ldots \ldots \ldots \ldots \ldots \ldots \ldots \ldots \ldots \ldots \ldots \ldots \ldots$

1. INTRODUCTION: MARKET ANALYSES DRIVE ACTIVE DESICCANT

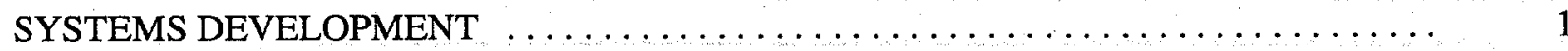

2. SUMMARY OF MARKET ANALYSES $\ldots \ldots \ldots \ldots \ldots \ldots \ldots \ldots \ldots \ldots \ldots \ldots \ldots \ldots$

2.1 SUMMARY OF PROMISING MARKETS FOR ACTIVE DESICCANT

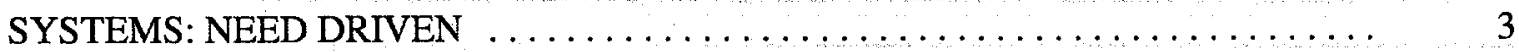

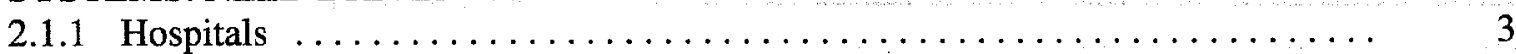

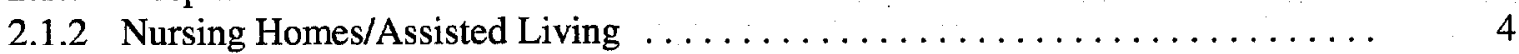

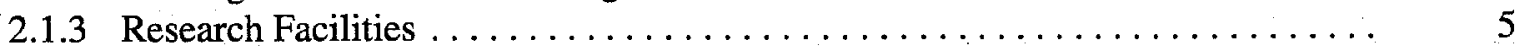

2.2 SUMMARY OF PROMISING MARKETS FOR ACTIVE DESICCANT

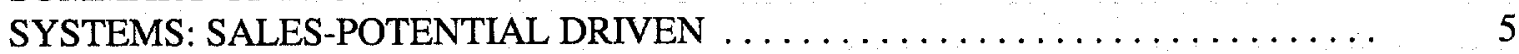

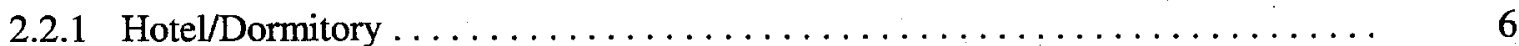

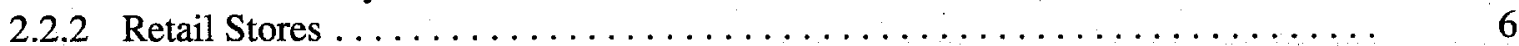

2.2.3 School Facilities . . . . . . . . . . . .

2.2.4 Positive Trends Impacting Active Desiccant System Solutions . . . . . . . . . . 9

3. PRODUCT DEVELOPMENT STRATEGY $\ldots \ldots \ldots \ldots \ldots \ldots \ldots \ldots \ldots \ldots \ldots \ldots .11$

3.1 LIMITING ACTIVE DESICCANT SYSTEMS OPTIONS FOR SUCCESSFUL

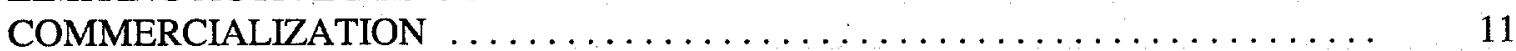

3.1.1 Traditional Desiccant-Based Cooling Approach . . . . . . . . . . . . . . 11

3.1.2 Desiccant Dehumidification-Total Energy Recovery Hybrid . . . . . . . . . 12

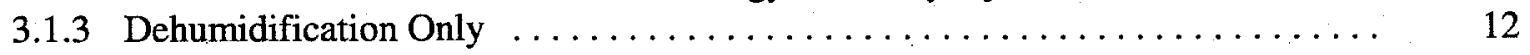

3.2 LIMITED ACTIVE DESICCANT SYSTEM OPTIONS MEET THE

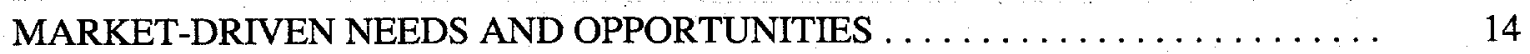

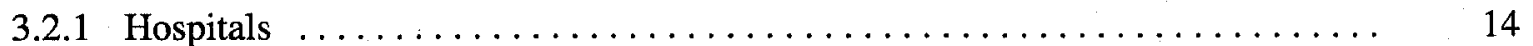

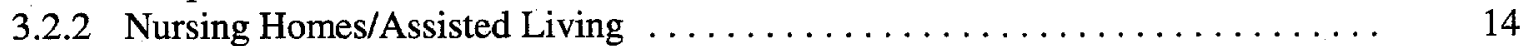

3.2 .3 Research Facilities . . . . . . . . . . . . . . . . . . . . . . . . 16

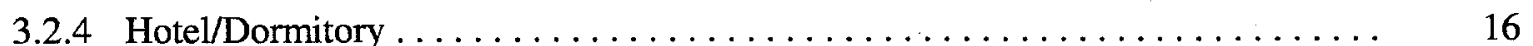

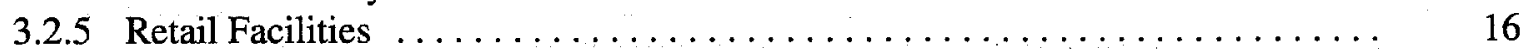

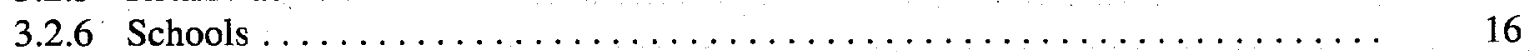

3.3 KEY DESIGN OBJECTIVES DRIVING ACTIVE DESICCANT SYSTEM

3.4 SYSTEM DESIGN OBJECTIVES SET THE PERFORMANCE GOALS

FOR THE ACTIVE DESICCANT WHEEL $\ldots \ldots \ldots \ldots \ldots \ldots \ldots \ldots \ldots \ldots \ldots$

4. PERFORMANCE MODELING: $\ldots \ldots \ldots \ldots \ldots \ldots \ldots \ldots \ldots \ldots \ldots \ldots \ldots \ldots \ldots \ldots$

4.1 ACTIVE DESICCANT WHEEL OPTIMIZATION TO MEET THE

MARKET-DRIVEN PERFORMANCE CRITERIA AND STATED

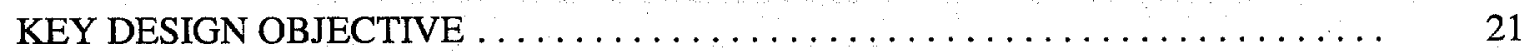

4.1.1 Wheel Size and Process/Regeneration Area Percentages . . . . . . . . . . . . . 21

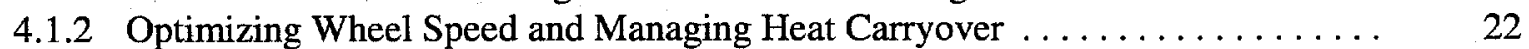

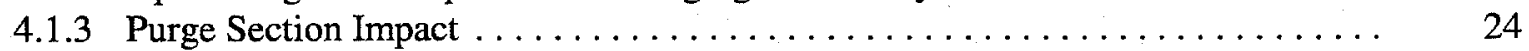

4.1.4 Benefit of Using the Heat Gradient of the Sensible Wheel . . . . . . . . . . . 24 


\subsection{REVISION OF MODELING USING NEW DESICCANT WHEEL PERFORMANCE DATA (TESTING COMPLETED IN}

TASKS 2 AND 6)

4.2.1 Improved Operating Costs of DBC and DH/ER Hybrid Approaches . . . . . . . 25

4.2.2 Impact of New ASHRAE Dew Point Design Data: Good and Bad

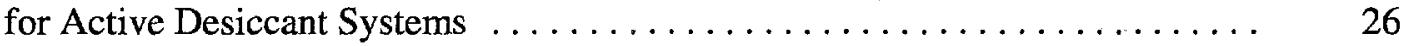

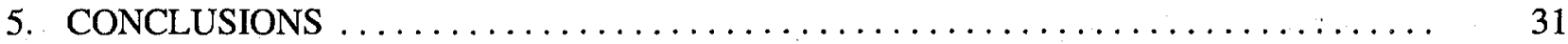

5.1 COMPARING SYSTEMS BASED ON LATENT AIR CONDITIONING

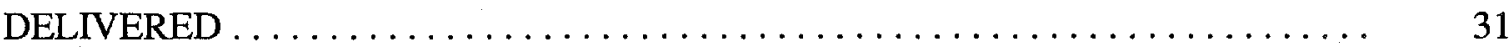

5.2 COMPARING SYSTEMS BASED ON COST PER TON OF LATENT

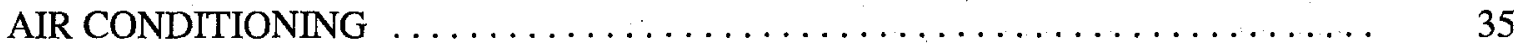

5.3 COMPARING SYSTEM OPERATING EFFICIENCY BASED ON

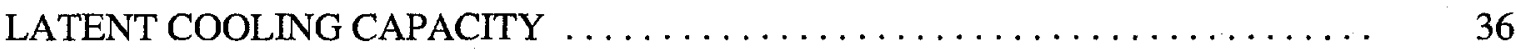

5.4 KEY CONCLUSIONS BASED ON TASK 2 WORK $\ldots \ldots \ldots \ldots \ldots \ldots \ldots \ldots \ldots$

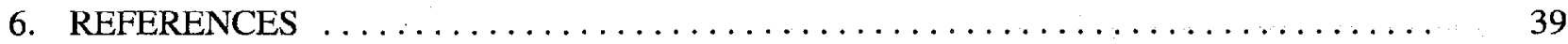

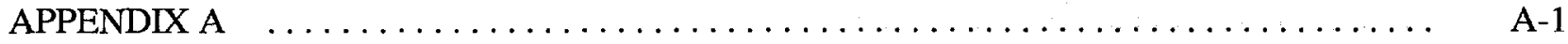




\section{FIGURES}

Page

1 Desiccant-based cooling (DBC) approach (from Climate Changer modules) $\ldots \ldots \ldots \ldots 11$

2 Desiccant-based cooling approach: typical configuration $\ldots \ldots \ldots \ldots \ldots \ldots \ldots \ldots$

3 Dehumidification-total recovery hybrid approach (from Climate

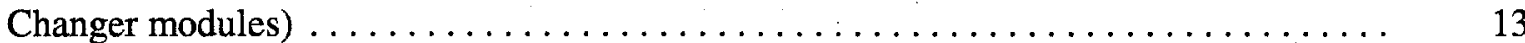

4 Dehumidification-total energy recovery hybrid system $\ldots \ldots \ldots \ldots \ldots \ldots \ldots \ldots \ldots$

5 Dehumidification-only approach (from Climate Changer modules) $\ldots \ldots \ldots \ldots \ldots$

6 Dehumidification-only assist to conventional cooling approach

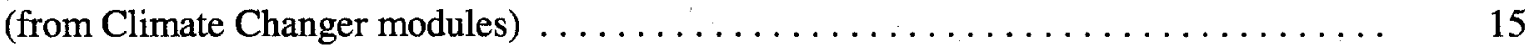

7 Sample performance comparison: SEMCO $1 \mathrm{M}$ and SEMCO MT wheels

with all conditions and operating parameters being equal. . . . . . . . . . . . . 19

8 High heat carry-over $\mathrm{DBC}$ flow diagram $\ldots \ldots \ldots \ldots \ldots \ldots \ldots \ldots \ldots \ldots \ldots \ldots \ldots$

$9 \quad$ Reduced heat carry-over $\mathrm{DBC}$ flow diagram $\ldots \ldots \ldots \ldots \ldots \ldots \ldots \ldots \ldots \ldots \ldots$

10 High heat carry-over with purge $\mathrm{DBC}$ flow diagram $\ldots \ldots \ldots \ldots \ldots \ldots \ldots \ldots \ldots$

11 High heat carry-over with purge and heat gradient $\ldots \ldots \ldots \ldots \ldots \ldots \ldots \ldots$

A.1 Annual operating cost estimate for the traditional desiccant-based

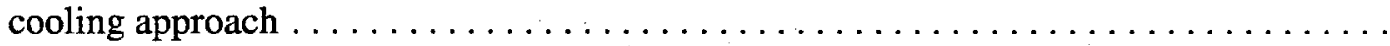

A.2 Annual operating cost estimate for the dehumidification/total energy

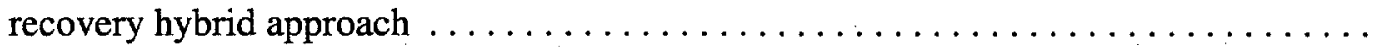

A.3 Annual operating cost estimate for the traditional desiccant-based cooling approach, modified to reflect the performance of the SEMCO $1 \mathrm{M}$ wheel

A.4 Annual operating cost estimate for the dehumidification/total energy recovery hybrid approach, modified to reflect the performance of the SEMCO $1 \mathrm{M}$ wheel

A.5 Flow schematic of typical active desiccant system performance for

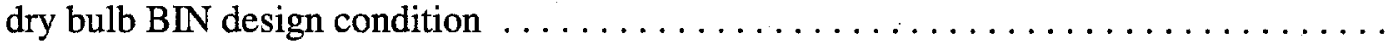

A.6 Flow schematic of typical active desiccant system performance for dew point design condition 
A.7 Flow schematic of dehumidification-total energy recovery system

performance for dry bulb BIN design condition $\ldots \ldots \ldots \ldots \ldots \ldots \ldots \ldots \ldots$

A.8 Flow schematic of dehumidification-total energy recovery system performance for dew point design condition $\ldots \ldots \ldots \ldots \ldots \ldots \ldots \ldots \ldots \ldots \ldots \ldots \ldots \ldots \ldots$ 


\section{TABLES}

Page

1 Projected annual sales potential for active desiccant systems in targeted markets .....

2 Selling price and dimensions of various preconditioning approaches

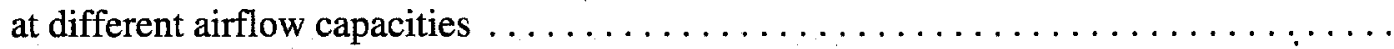

3 Active desiccant approach most likely to be used in targeted markets $\ldots \ldots \ldots \ldots$

4 Comparison of Climate Changer design airflow rates with dehumidification wheel geometry and face velocity $\ldots \ldots \ldots \ldots \ldots \ldots \ldots \ldots \ldots \ldots \ldots \ldots \ldots \ldots \ldots \ldots$

5 Simple payback of various preconditioning approaches at different

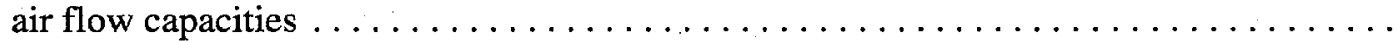

6 Comparison of humidity design data: dry bulb and mean coincident wet bulb (MCWB) and mean coincident dry bulk (MCDB) data vs dew point design . . . . . . . 28

7 Impact of new ASHRAE weather data (wet bulb BINS, corresponding dry bulb) . . . . 29

8 Conventional overcooling with reheat preconditioning approach $\ldots \ldots \ldots \ldots \ldots \ldots$

9 Desiccant-based cooling preconditioning approach $\ldots \ldots \ldots \ldots \ldots \ldots \ldots \ldots \ldots$

10 Dehumidification-total energy recovery hybrid $\ldots \ldots \ldots \ldots \ldots \ldots \ldots \ldots \ldots \ldots \ldots$

11 Comparison of the estimated first cost based on both total and latent cooling tonnage provided: conventional overcooling vs DBC approach $\ldots \ldots \ldots \ldots \ldots \ldots$

12 Comparison of the estimated first cost based on both total and latent cooling tonnage provided: conventional overcooling vs dehumidification-total

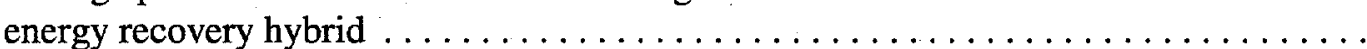

13 Comparison of system latent cooling COP based on dew point design data $\ldots \ldots \ldots .38$ 


\section{INTRODUCTION: MARKET ANALYSES DRIVE ACTIVE DESICCANT SYSTEMS DEVELOPMENT}

The Phase 1 report (ORNL/Sub/94-SV044/1), completed earlier in this program, involved a comprehensive field survey and market analysis comparing various specialized outdoor air handling units. This initial investigation included conventional cooling and reheat, conventional cooling with sensible recovery, total energy recovery systems (passive desiccant technology) and various active desiccant systems. The report concluded that several markets do promise a significant sales opportunity for a Climate Changer-based active desiccant system offering. (Climate Changer is a registered trademark of Trane Company.) This initial market analysis defined the wants and needs of the end customers (design engineers and building owners), which, along with subsequent information included in this report, have been used to guide the determination of the most promising active desiccant system configurations.

This Phase 2 report begins with a summary of a more thorough investigation of those specific markets identified as most promising for active desiccant systems. Table 1 estimates the annual sales potential for a cost-effective product line of active desiccant systems, such as that built from Climate Changer modules.

The Product Development Stratcgy scction describes the active desiccant system configurations chosen to best fit the needs of the marketplace while minimizing system options. Key design objectives based on market research are listed in this report for these active desiccant systems. Corresponding performance goals for the dehumidification wheel required to meet the overall system design objectives are also defined.

Table 1. Projected annual sales potential for active desiccant systems in targeted markets

\begin{tabular}{lccc}
\hline \multicolumn{1}{c}{ Application category } & $\begin{array}{c}\text { DBC approach } \\
(\mathbf{S M})\end{array}$ & $\begin{array}{c}\text { Total recovery } \\
\text { desiccant DH hybrid } \\
(\mathbf{S M})\end{array}$ & $\begin{array}{c}\text { Dehumidification } \\
\text { stand-alone module } \\
(\mathbf{M})\end{array}$ \\
\hline Nursing homes/assisted living (1) & 4.75 & 4.04 & \\
Hospitals and operating rooms & & 8.65 & 4.14 \\
Research laboratories & 6.24 & & 0.98 \\
Retail stores (1) & 6.24 & 3.75 & 2.5 \\
Hotcls, dormitorics (1) & 6.24 & 6.24 & 3.12 \\
School and university classrooms & & 25.65 & \\
\multicolumn{1}{c}{ Subtotal by product } & 23.47 & 48.32 & 10.73 \\
\hline
\end{tabular}

Note 1: Significant penetration into this market is contingent upon a low-cost, commercial product to augment packaged HVAC equipment.

Note 2: This table estimates sales potential on an annual basis and assumes compliance with ASHRAE 62-89.

Note 3: Sales potential dollars assume a Climate Changer offering priced as per Table 2. 
The Performance Modeling section describes the strategy used by SEMCO to design the dehumidification wheels integrated into the prototype systems currently being tested as part of the U.S. Department of Energy's Advanced Desiccant Technology Program. Actual performance data from wheel testing was used to revise the system performance and energy analysis modeling initially presented in the Phase 1 report. This section also provides a revised payback analysis comparing the active desiccant systems selected with the other, more conventional approaches to specialized outdoor air handling units listed in the Phase 1 report.

This report concludes with a look at the importance of analyzing active desiccant systems on the basis of "latent air conditioning" and not the more traditional "total cooling capacity". Since handling latent load will always be the primary reason for using an active desiccant system, it is concluded that the technology must be positioned as a "latent air conditioner" in the marketplace. In past analyses, active desiccant systems have been too often compared with conventional cooling systems based on total cooling output. The resulting $\$$ /ton ratios that have resulted almost always made the active approach appear as if a very significant firstcost premium were required.

The tables in Sect. 5 show that when the most promising active desiccant systems are compared with a conventional cooling approach based on latent capacity, both the first cost and operating efficiency are found to be similar. The active desiccant systems have the advantage of lower operating cost because they use gas rather than electricity. This and other performance advantages make the active desiccant approach an attractive design alternative in the targeted markets. 


\section{SUMMARY OF MARKET ANALYSES}

\subsection{SUMMARY OF PROMISING MARKETS FOR ACTIVE DESICCANT SYSTEMS: NEED DRIVEN}

The Phase 1 market evaluation for active desiccant systems concluded that several markets have a high level of need for the dehumidification capabilities offered by active desiccant systems. These markets include hospitals, nursing homes, and research facilities. The need is driven by a quantifiable benefit and/or importance associated with controlling space relative humidity at (or sometimes below) $50 \%$ during the cooling season, combined with a desire or need to provide high percentages of outdoor air on a continuous basis.

A secondary level of need is associated with reducing the cost of operation of these facilities. Given that these facility types are generally constructed to be owner-occupied and to have a long life cycle, and that they typically have waste or low-cost energy available during the cooling season (excess steam or low-cost gas), the humidity control desired will often be achieved most economically using some type of active desiccant approach. Owner-occupied facilities are often more interested in the long-term operating costs than first cost, one of the most common impediments to integrating active desiccant systems.

In an attempt to determine which of the many active desiccant system approaches best fit the specific needs of these need-driven markets, each was analyzed to determine which approach was most easily integrated into current design schemes. The specific drivers behind increased ventilation and humidity control were also determined for each market. This market-by-market analysis provided the basis for deciding which active desiccant approach(s) would best fit each market and what performance, cost, size and other parameters would be most important. The following information provides a summary of these analyses.

\subsubsection{Hospitals}

Hospitals are bound by charter to do no harm to their patients. Humidity control is very important in hospital facilities because it has been well established that there exists a strong relationship between space relative humidity and airborne infectious diseases. There are many sources for information on this topic; one of the best sources is a paper by Arundel et al. (1986). (This paper is the source of the Optimum Relative Humidity Range diagram referenced in the ASHRAE 62-89 IAQ Standard).

One body of evidence demonstrates that mid-range relative humidities (defined as between 40 and 60\%) are more lethal to airborne bacteria than lower or higher relative humidities. Bacteria cause pneumonia, tuberculosis, anthrax and Legionnaire's disease, all of which are air-transmitted. Nonpathogenic bacterial infections such as streptococcus and staphylococcus have also been shown to be less viable in space conditions controlled at $50 \%$ relative humidity.

Research conducted to determine the space relative humidity required to minimize the risk of viral infections (such as influenza) suggests an optimum range between approximately 40 and $70 \%$ relative humidity.

It is also well established that the greater the ventilation rate, the lower the colony count (concentration) of the airborne pathogens. There is strong correlation between the colony count and the incidence of infection. In fact, it is suggested by Arundel et al. (1986) that where high air change rates exist, the humidity control impact is very small, and therefore, less important. 
This basic research provides a quantitative, compelling reason to provide high quantities of outdoor air to hospitals while maintaining the space relative humidity between approximately 40 and $60 \%$.

Two additional, important factors favor the use of active desiccant systems in hospital facilities. First, they allow operation of the facility (specifically the operating rooms) with dry cooling coils. This is a significant advantage since the most common design approach used today minimizes the outdoor air quantity by employing high-efficiency filters (handling increased recirculated air rates) downstream of the cooling coils. The justification is that bacteria and viruses are large enough to be filtered out, so dilution ventilation can be greatly reduced.

The serious flaw in this approach is that engineers almost never recognize the need for a sizable reheating coil after the cooling coil to avoid saturated air, which wets the final filter bank. Wet filters can exacerbate the very problem that they are designed to eliminate by serving as an amplification site for microbial growth. This is a common and serious problem in hospitals. Active desiccant systems can dehumidify the recirculated air sufficiently that the air leaving the cooling coils does not wet the final filters.

The second key advantage is that the active desiccant system can provide the optimum relative humidity (40 to 50\%) in operating rooms even when the space temperature is controlled to as low as 62 to $65^{\circ} \mathrm{F}$. This low space temperature has become very common because of the high density of electronics and lights now common in operating rooms, linked with the added protective gear worn by personnel because of the concern about exposure to AIDS and about other liability issues. It is also common during certain surgical procedures, such as heart surgery, to maintain very low space temperatures to improve the success rate of the procedure. Many surgeons fight with the hospital facilities group because they are given the choice of either comfortable conditions (cool space) or optimum space humidity. They need both. Current practice is to cool to $55^{\circ} \mathrm{F}$ and control the space temperature at $62^{\circ} \mathrm{F}$, resulting in a space relative humidity of $75 \%$. This market is searching for a cost-effective, compact solution.

As a result, the opportunity for active desiccant systems built from Climate Changer modules is significant for the hospital market. As is discussed later, the best solutions for this market will range from dehumidification-only units to dehumidification/total energy recovery hybrid systems.

\subsubsection{Nursing Homes/Assisted Living}

Critical care nursing homes (facilitics for the very elderly or those in need of critical care) are designed similarly to a hospital facility's patient care area. In some ways, humidity control and indoor air quality are even more critical since all of the patients are elderly and therefore more susceptible to discomfort and infection. As a result, these types of facilities have the same ventilation and humidity control requirements as hospital patient care facilities.

Since the elderly are generally more comfortable at higher space temperatures (say $78^{\circ} \mathrm{F}$ ), the level of dehumidification required to maintain the relative humidity at $50 \%\left(56^{\circ} \mathrm{F}\right.$ dew point $)$ is significantly less than for a hospital operating room operated at $65^{\circ} \mathrm{F}\left(45^{\circ} \mathrm{F}\right.$ dew point). Therefore, it can be reached with conventional cooling equipment quite easily. Based on market research and project history, the ventilation requirements for these facilities are driven more by a desire to keep odor levels low (no one wants to place a loved one in a smelly environment); as a result, these facilities are typically designed to have a high percentage of outdoor air.

According to the building statistics and market observations, the number of critical care type facilities constructed each year is declining as a result of the significant rise in the construction of assisted living facilities. These assisted living facilities, marketed by huge organizations such as Marriott and Service 
Master, are being built at a very high rate. Demographics suggest that this rate should remain strong for some time. Based on preliminary discussions with the designers of these facilities and on review of current design practices, they are more like condominiums than hospitals. As a result, they are typically built using packaged equipment (i.e., heat pumps in each room) with corridor delivery of outdoor air to compensate for kitchen and/or bathroom exhaust.

In both cases there are compelling reasons to control humidity and ventilate. The opportunity for active desiccant systems based upon a Climate Changer product will most likely be limited to the critical care type of facilities that are currently in decline. The assisted living facilities would be served very well (in humid climates) by a product designed to augment conventional packaged rooftop units to provide $100 \%$ outdoor air to the corridors. If an exhaust air path is available, such a product would likely be a dual wheel passive system. If an exhaust air path is not available, an active desiccant module linked with a packaged rooftop air conditioner, such as the Voyager product line manufactured by Trane, would best fit the needs of this market.

\subsubsection{Research Facilities}

Research facilities offer an exceptional opportunity for applying regenerated desiccant systems. They require high percentages of outdoor air to replace the air exhausted from fume hoods, animal areas, and so on. Most research facilities require humidity control - not necessarily low humidity, but steady humidity typically in the range of $50 \%$. These facilities currently demand mechanical equipment of at least the complexity and quality offered by the Climate Changer. It is generally understood by those designing laboratory facilities that the cost of operation is very high, so these projects are not often first-cost driven (making the initial firstcost premium associated with a desiccant system less an issue than in other markets). Research facilities also typically overcool and reheat to maintain space humidity, so pay-back periods for active desiccant systems can be short. Payback cycles are significantly improved by the availability of low-cost steam for regeneration during the cooling season, which is often available.

An added benefit that some active desiccant systems can provide to a research facility is the ability to remove airborne pollutants from the outdoor air along with the adsorbed water vapor. Initial testing in this area looks very promising. More follow-up research is planned to verify this benefit, including measurements at actual installation sites.

Active desiccant systems based upon a Climate Changer format will meet the needs of this market segment in most cases. Research facilities often have numerous exhaust fans that cannot be easily connected together and deal with chemical contaminant concentrations that may not be suitable for recovery (in the opinion of the owner or designer). Therefore, the conventional DBC approach (discussed later) provides the most attractive active desiccant system solution because it does not require access to an exhaust air path.

\subsection{SUMMARY OF PROMISING MARKETS FOR ACTIVE DESICCANT SYSTEMS: SALES-POTENTIAL DRIVEN}

The SEMCO Phase 1 report also concluded that several markets have only a moderate level of need but still offer a high level of sales potential for a cost-effective active desiccant system. These markets include hotels/dormitories, retail stores, and school facilities. The sales potential is driven by the fact that many of these types of facilities are constructed each year compared with the number of hospitals, nursing homes, and research facilities. If only a small percentage of these facilities chose to utilize active desiccant approaches, the potential sales volume increase for an active desiccant system, such as that delivered in Climate Changer modules, would be significant. 
In these market segments, benefits such as low operating cost (associated with low-cost fuel or waste heat) or dry cooling coils associated with the active desiccant approach must offset the familiarity factor, compact size, and lower first cost typically associated with more conventional approaches.

\subsubsection{Hotel/Dormitory}

This market segment is currently quite active because of renovations and acquisitions of various hotel facilities, as well as a healthy expansion in new construction. The mechanical design approach used for these facilities is similar to that described for assisted living facilities. Hotels are not driven by the same health-related issues associated with hospitals and nursing homes. They are affected by wide humidity fluctuations associated with the room layout (showers in each room) and the inability of the room air conditioning units to handle these high latent conditions.

As a result, a direct cost can be attributed to humidity problems (e.g., mold, mildew) in hotel and dormitory rooms. A study available from the Gas Research Institute (Collier 1988) and conducted by Cargocaire Engineering quantifies the benefits of improved humidity control within hotel facilities. The need and justification for improved indoor air quality and, specifically, improved humidity control is relatively clear for hotel facilities. This market has not evolved, however, since the successful test site demonstration completed by Cargocaire and GRI more than 5 years ago. The reason is likely a perception of high first cost and the lack of effective sales distribution to the large national accounts that purchase most of the HVAC equipment sold to the hotel construction market.

An active desiccant system offering by Trane would overcome the distribution obstacle because Trane is best positioned, because of its access to national accounts, to change the way hotels are designed and operated. A fully commercialized active desiccant system offering by Trane would be far more costeffective than options currently available that would also accelerate market acceptance.

A recent survey of several Trane sales offices supports these conclusions. The salcspeople in these offices were aware of the need for an outdoor air preconditioner for hotel/dormitory and assisted living facilities and recognized these as growing markets. They also acknowledged that Trane did not currently have an effective product to meet the needs of these markets. As a result, most were selling non-Trane products to meet the needs of such projects.

Several 5000-cfm, packaged overcooling/reheating units originally designed for swimming pool dehumidification have been sold by Trane for $\$ 39,000$, or approximately $\$ 8 / \mathrm{cfm}$. Based on this pricing level, an active desiccant system offering by Trane would be both energy efficient and cost competitive (\$5/cfm is a good estimate of the selling price of a 5000-cfm Climate Changer-based DBC system, according to Table 2).

\subsubsection{Retail Stores}

The market potential for regenerated desiccant systems in retail stores is primarily limited to the new trend toward super-stores that include a grocery section. Retail stores with refrigerated food cases (i.e., supermarkets) are one of the few markets that have already accepted regenerated desiccant systems. The 
Table 2. Selling price and dimensions of various preconditioning approaches at different airflow capacities

\begin{tabular}{|c|c|c|c|c|c|c|}
\hline \multirow[b]{2}{*}{ Preconditioning system approach } & \multicolumn{2}{|c|}{$2,500 \mathrm{cfm}$} & \multicolumn{2}{|c|}{$7,500 \mathrm{cfm}$} & \multicolumn{2}{|c|}{$20,000 \mathrm{cfm}$} \\
\hline & Sales price ${ }^{a}$ & $\begin{array}{l}\text { Dimensions }^{b} \\
(\mathrm{H} \times \mathrm{W} \times \mathrm{L})\end{array}$ & Sales price & $\begin{array}{l}\text { Dimensions } \\
(\mathrm{H} \times \mathrm{W} \times \mathrm{L})\end{array}$ & Sales price & $\begin{array}{l}\text { Dimensions } \\
(\mathrm{H} \times \mathrm{W} \times \mathrm{L})\end{array}$ \\
\hline Conventional cooling w/reheat & $\begin{array}{c}\$ 2,200 \\
(\$ 9,500)\end{array}$ & $27.5 \times 44 \times 154$ & $\begin{array}{c}\$ 7,100 \\
(\$ 28,500)\end{array}$ & $44 \times 74 \times 177$ & $\begin{array}{c}\$ 16,700 \\
(\$ 76,000)\end{array}$ & $74 \times 120 \times 251$ \\
\hline Conventional cooling w/run around recovery & $\begin{array}{c}\$ 4,000 \\
(\$ 7,750)\end{array}$ & $55 \times 44 \times 141$ & $\begin{array}{c}\$ 12,150 \\
(\$ 23,250)\end{array}$ & $88 \times 74 \times 193$ & $\begin{array}{c}\$ 31,000 \\
(\$ 62,000)\end{array}$ & $148 \times 120 \times 260$ \\
\hline Total energy wheel w/cooling and reheat & $\begin{array}{c}\$ 7,000 \\
(\$ 5,500)\end{array}$ & $55 \times 44 \times 171$ & $\begin{array}{l}\$ 16,750 \\
(\$ 17,000)\end{array}$ & $88 \times 74 \times 194$ & $\begin{array}{c}\$ 37,300 \\
(\$ 45,000)\end{array}$ & $148 \times 120 \times 268$ \\
\hline Dual wheel total energy recovery & $\begin{array}{l}\$ 11,100 \\
(\$ 3,500)\end{array}$ & $55 \times 44 \times 188$ & $\begin{array}{c}\$ 24,750 \\
(\$ 10,500)\end{array}$ & $88 \times 74 \times 211$ & $\begin{array}{c}\$ 53,650 \\
(\$ 28,000)\end{array}$ & $148 \times 120 \times 285$ \\
\hline Dual wheel desiccant based (DBC) w/post cooling & $\begin{array}{l}\$ 14,700 \\
(\$ 2,000)\end{array}$ & $55 \times 44 \times 188$ & $\begin{array}{l}\$ 30,200 \\
(\$ 6,000)\end{array}$ & $88 \times 74 \times 211$ & $\begin{array}{c}\$ 64,800 \\
(\$ 16,000)\end{array}$ & $148 \times 120 \times 285$ \\
\hline Desiccant dehumidification-total recovery hybrid & $\begin{array}{l}\$ 15,750 \\
(\$ 3,000)\end{array}$ & $55 \times 44 \times 203$ & $\begin{array}{l}\$ 31,350 \\
(\$ 8,500)\end{array}$ & $88 \times 74 \times 226$ & $\begin{array}{c}\$ 67,850 \\
(\$ 22,500)\end{array}$ & $148 \times 120 \times 300$ \\
\hline Dual wheel DBC-total recovery hybrid & $\begin{array}{l}\$ 20,500 \\
(\$ 1,000)\end{array}$ & $55 \times 44 \times 235$ & $\begin{array}{l}\$ 39,300 \\
(\$ 3,250) \\
\end{array}$ & $88 \times 74 \times 258$ & $\begin{array}{l}\$ 84,200 \\
(\$ 8,500) \\
\end{array}$ & $148 \times 120 \times 332$ \\
\hline
\end{tabular}

${ }^{a}$ All sales prices are estimates of the market price using Climate Changer modules.

${ }^{b}$ All dimensions assume the use of Trane Climate Changer modules and SEMCO wheel modules.

${ }^{c}$ Numbers in parentheses denule cost of chiller and cooling tower capacity required to takc outdoor air at $95^{\circ} \mathrm{F} / 115$ grains to 50 grains assuming a cost of $\$ 500 /$ ton. 
justification for the desiccant system is its ability to keep the humidity level low enough in areas around the frozen food cases that frosting on the product and within the casings is minimized.

Avoiding frost formation translates into reduced operating costs (from limiting expensive defrost cycles of the cases) and increased sales due to better presentation of the product and customer comfort (warmer aisles). If customers are comfortable, they spend more time in the stores and therefore purchase more products.

One obstacle to penetration into this market segment by Trane is that the Climate Changer is an indoor product and most of the current designs for super-stores use outdoor, compressorized equipment. As a result, this market segment may be better suited to a hybrid desiccant system based on a unitary rooftop air conditioner such as those Trane makes in Clarksville, rather than to a Climate Changer system.

In humid climates, retail stores that do not include food sections with refrigerated cases may still present a limited market opportunity for regenerated desiccant systems if the outdoor air volume equals that required for building pressurization (air leaking through doors). This results in a design where exhaust air is not available for use with desiccant-based energy recovery (passive wheels). A rooftop/active desiccant hybrid system could reduce the overall number of rooftop units installed on a typical retail store and better handle the part load conditions while reducing the cost of operation in humid climates where the gas cost/electrical cost ratio is low.

If the outdoor air volume required by indoor air. quality regulations is greater than that required for pressurization, then a passive desiccant approach would be chosen most often, since it is less costly and will usually save more energy because it is a year-round technology (i.e., it provides significant heating season energy savings).

\subsubsection{School Facilities}

Given that school facilities often have an exhaust air stream available for recovery using passive desiccant wheels (or other recovery approaches), the opportunity for active desiccant systems continues to be either hybrid systems where the energy rejected from an engine-driven chiller is used for regeneration or where the benefit of maintaining "dry" cooling coils is considered very significant. A more thorough investigation of this market completed since the initial Phase 1 report further supports this conclusion.

An active desiccant offering made available in the Climate Changer product line would be limited primarily to school facilities designed with central chilled water systems located in humid climates, where waste heat is available or where the electrical cost/gas cost ratio is extremely high.

Considering these limitations, the percentage of schools constructed that would be viable candidates for an active desiccant system based upon a Climate Changer approach would likely be small. Once again, however, the number of schools constructed each year is very large, and even a small percentage may provide a large salcs potential for Trane if its distributors market aggressively.

One potential market driver for active desiccant systems in schools is the increased awareness of the rise in the incidence of asthma, specifically among children. Numerous papers on this topic were presented at the worldwide indoor air quality conference held in Washington, D.C., in the fall of 1997. Two papers presented at the conference (Hodgson 1997; Bascom 1997) confirmed a rise in asthma cases-as well as other lung diseases and allergic conditions-among children and linked the increase in part to high humidity and/or mold and microbial infestation (which can be directly attributed to lack of adequate humidity control in humid climates). 
(These papers and others presented at IAQ 1997 are collected in a proceedings, which can be obtained from the American Socicty of Heating, Refrigerating and Air-conditioning Engineers).

As more research is completed in this area, especially in the school environment where children spend a large portion of their time during the developmental years (when most asthma occurs), and if it is shown that humidity is a major contributor to the asthma "epidemic," then the argument for dry cooling coils and careful, year-round humidity control is likely to become widely accepted.

This scenario would significantly increase the market opportunity for active desiccant systems in school facilities as well as in the hotel/dormitory markets.

SEMCO has already observed first-hand the positive impact that effective humidity control has had on avoiding (in new construction) and eliminating (in retrofits) microbial activity in school facilities. We are hopeful that the school investigations being conducted by the Georgia Tech Research Institute and Georgia State University as part of Phase 2 of this program will provide quantitative evidence to support these observations.

\subsubsection{Positive Trends Impacting Active Desiccant System Solutions}

In addition to the market drivers already mentioned (e.g., conformance with ASHRAE 62-89, the relationship of high humidity to asthma), current trends in the design community and utility deregulation favor an increase in future market potential for active desiccant systems.

The 1997 ASHRAE Fundamentals has provided easy access to the true humidity design criteria for the entire country. As discussed in the Phase 1 report and shown in Table 6, the dew point design condition typically has a higher overall enthalpy value than the value obtained from the previously utilized dry bulb/wet bulb BIN data. More important, this table shows that the grain levels are much higher than previously thought by most engineers and that the sensible temperature that corresponds with this humidity design condition is likewise more moderate.

In short, outdoor air has a much higher latent-to-sensible load ratio than previously considered by most designers; this favors active desiccant systems and presents performance challenges to conventional compressor-driven, vapor compression equipment.

A growing number of design engineers are beginning to understand the benefits associated with providing outdoor air preconditioners to manage the increased latent loads resulting from accommodation to the ASHRAE 62 standard. The major HVAC equipment suppliers, such as Trane, are also beginning to promote conventional couling methods of preconditioning such as dual path systems, over-cooling with compressor reheating units, and passive energy recovery. Acceptance of this fundamental change in the way systems are designed should proliferate as the impact of increased latent loads is better understood by more designers and end customers. This trend will greatly simplify the marketing of active desiccant systems.

GRI has been working to provide comprehensive weather data on an hour-by-hour basis that would allow completion of energy analyses that can accurately reflect the impact of latent outdoor air loads. According to Lew Harriman of Mason Grant, who has worked with GRI on this project, this comprehensive data base provides improved energy savings results over those provided by the current ASHRAE weather database. As these data are integrated into tools for engineers to evaluate the cost of conditioning outdoor air, the projected payback periods for active desiccant systems will shorten. 
The analysis tool developed by SEMCO and Kirk Collier as part of this program is nearing completion (a beta copy is available for evaluation). These types of tool are badly needed to educate designers and owners. SEMCO will investigate the possibility of integrating the hour-by-hour weather data now available from GRI to further improve the accuracy of the comparative systems modeling.

Utility deregulation has started a trend toward mega-utility companies that provide both gas and electric energy. According to the experts, this trend will likely result in higher electrical demand charges during peak use periods, more time of day rates reflecting the true cost to the electrical service provider, and more energy service companies that will be looking for ways to use gas during peak electrical periods. 


\section{PRODUCT DEVELOPMENT STRATEGY}

\subsection{LIMITING ACTIVE DESICCANT SYSTEMS OPTIONS FOR SUCCESSFUL COMMERCIALIZATION}

As discussed at length in the Phase 1 report, there are numerous ways to configure an active desiccant system. The benefit of the Climate Changer approach is that the modules can be arranged in many different configurations, offering the flexibility to tailor the system to the needs of each individual market. On the other hand, this relatively new technology needs to be presented to sales distributors and end customers in a pre-designed, easy-to-use format, or the benefits will be lost because complex engineering requirements increase the likelihood of misapplication.

Based on the market analysis portion of this program, it has been concluded that the needs of the target markets can be met effectively with a limited number of system configurations. Schematics of these configurations are shown as Figs. 1 through 6 . A summary of the function and strength of each approach is provided below.

\subsubsection{Traditional Desiccant-Based Cooling Approach}

The desiccant-based cooling (DBC) system uses a desiccant dehumidification wheel and a sensible-only energy recovery wheel, plate, or pipe to provide dehumidified outdoor air at a temperature that is similar to the outdoor air condition (see Figs. 1 and 2) prior to post-cooling. At moderate humidity conditions, this system approach can also provide indirect evaporative cooling to assist sensible cooling.

This approach is best suited for applications where an exhaust air path is not available for passive energy recovery. If it is available, the desiccant dehumidification-total energy recovery approach or other passive energy recovery options would likely be far more efficient, and often less costly. For this reason,

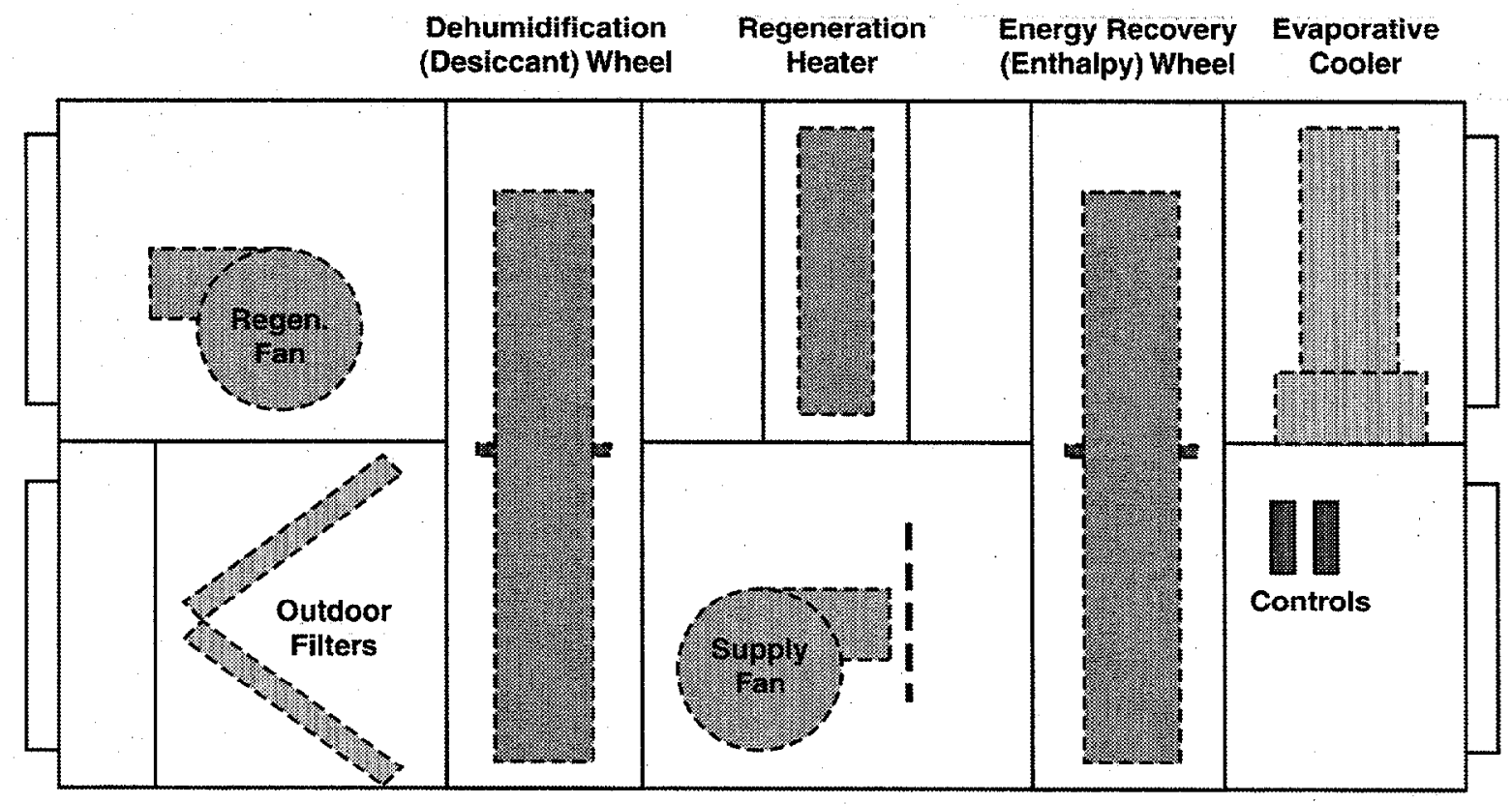

Fig. 1. Desiccant-based cooling (DBC) approach (from Climate Changer modules). 


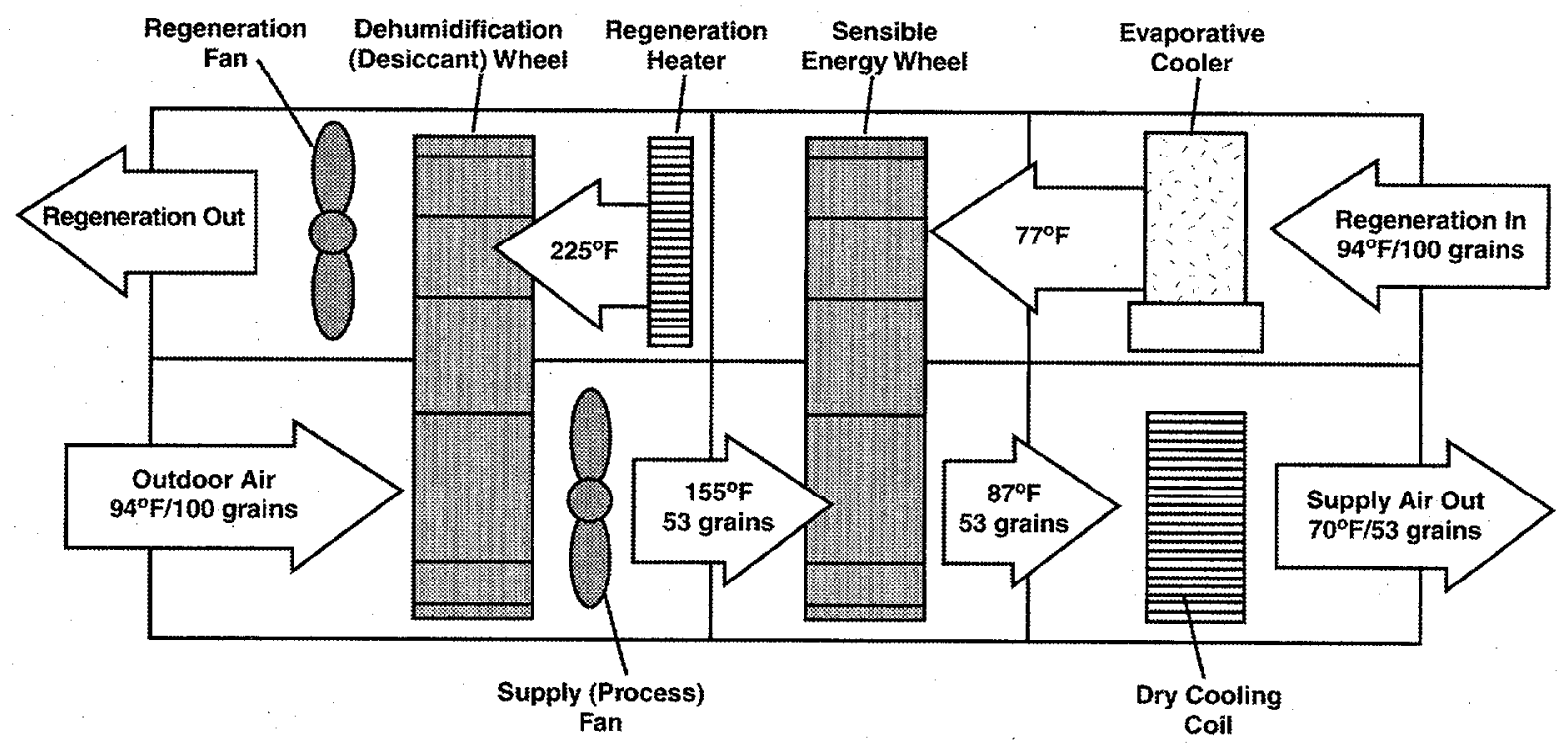

Fig. 2. Desiccant-based cooling approach: typical configuration.

a DBC unit is generally deactivated during the heating season, although sensible recovery is an option if an exhaust air path is used for regeneration.

\subsubsection{Desiccant Dehumidification-Total Energy Recovery Hybrid}

The desiccant dehumidification-total energy recovery system uses a desiccant dehumidification wheel and a passive total energy recovery wheel to provide much lower humidity levels more efficiently than is possible with the traditional DBC approach (Figs. 3 and 4). This approach requires a return air path for the total energy recovery wheel; the traditional DBC approach is typically applied without the need for a return air path.

This dehumidification-total recovery hybrid approach provides total energy recovery during the heating season, significantly reducing the payback period. It also eliminates the evaporative cooler used in the DBC approach, a fact often considered a plus because of the maintenance costs and the concerns about microbial activity and odors that are sometimes associated with evaporative coolers.

\subsubsection{Dehumidification Only}

The dehumidification-only module is used with conventional cooling approaches to provide the required dehumidification without the use of the sensible-only or total energy recovery wheel (Figs. 5 and 6 ). The advantage of this approach is compact size and, in some cases, a lower first cost. In most cases the operating cost will be high compared with the first two approaches, and no winter time recovery is provided. It will be common to have space limitations drive projects toward this approach despite the operational cost advantages of the others, since active desiccant systems will always be much larger than their conventional counterparts.

This approach would typically involve precooling to reduce the grain level of the air entering the dehumidification wheel while simultaneously raising its relative humidity, a process that increases the grain depression of the dehumidification wheel. The heat of adsorption and carryover associated with the dehumidification process would be handled by post-cooling or simply mixed with a cool airstream to provide the desired mixed air temperature. 


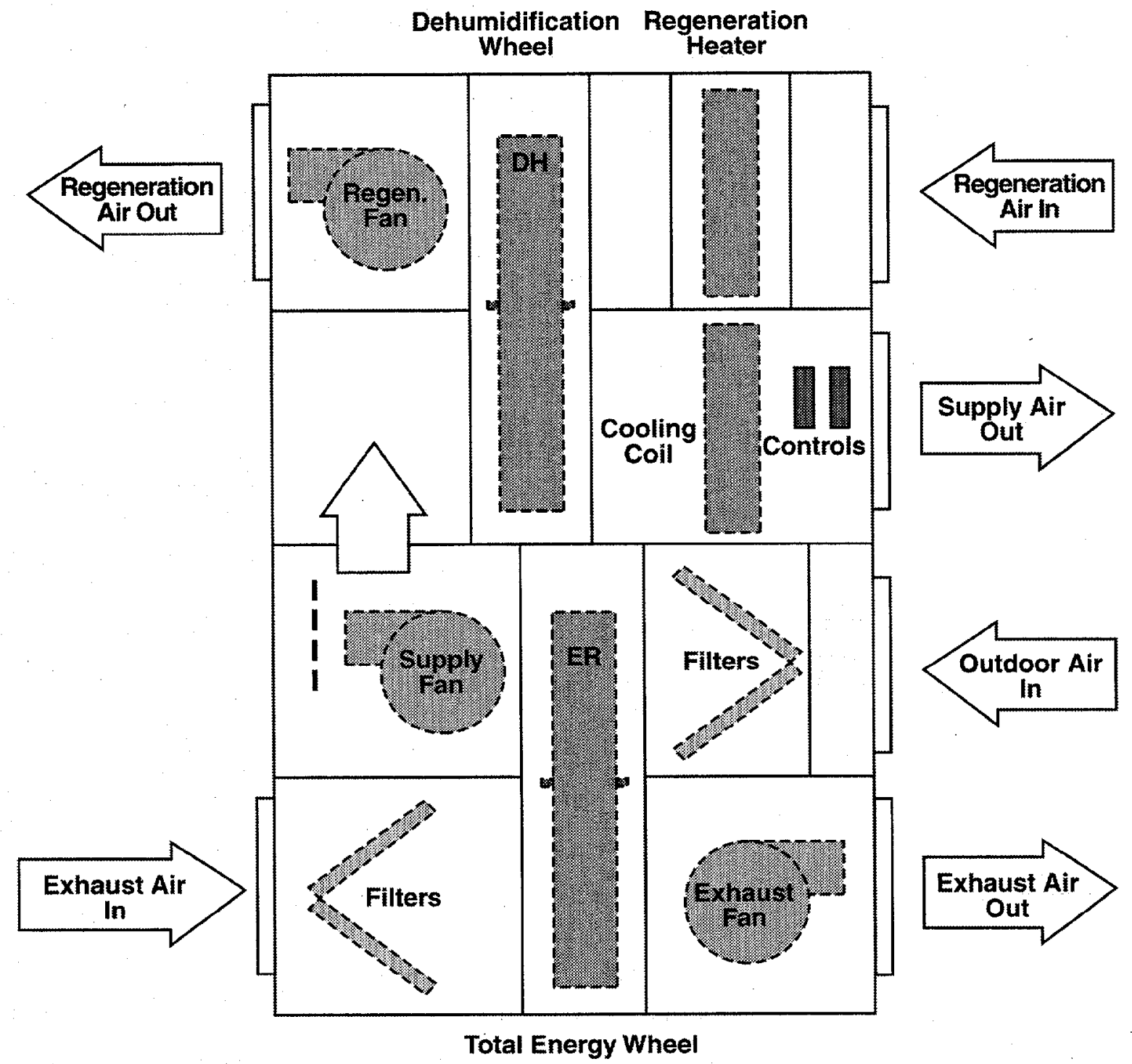

Fig. 3. Dehumidification-total recovery hybrid approach (from Climate Changer modules).

Given the flexibility of the Climate Changer offering, these three system configurations represent only two new configurations because the dehumidification-total energy recovery hybrid (Fig. 3) is simply a combination of Trane's existing total energy recovery wheel system with the dehumidification-only module shown in Fig. 5. Likewise, the dehumidification-only module shown in Fig. 5 is simply the dehumidification half of the traditional DBC approach shown in Fig. 1.

As a result, the goal of being able to meet the needs of the most attractive markets for an active desiccant system approach is easily met with only a few customized Climate Changer modules, and the system configurations required can be limited to three straightforward solutions. 


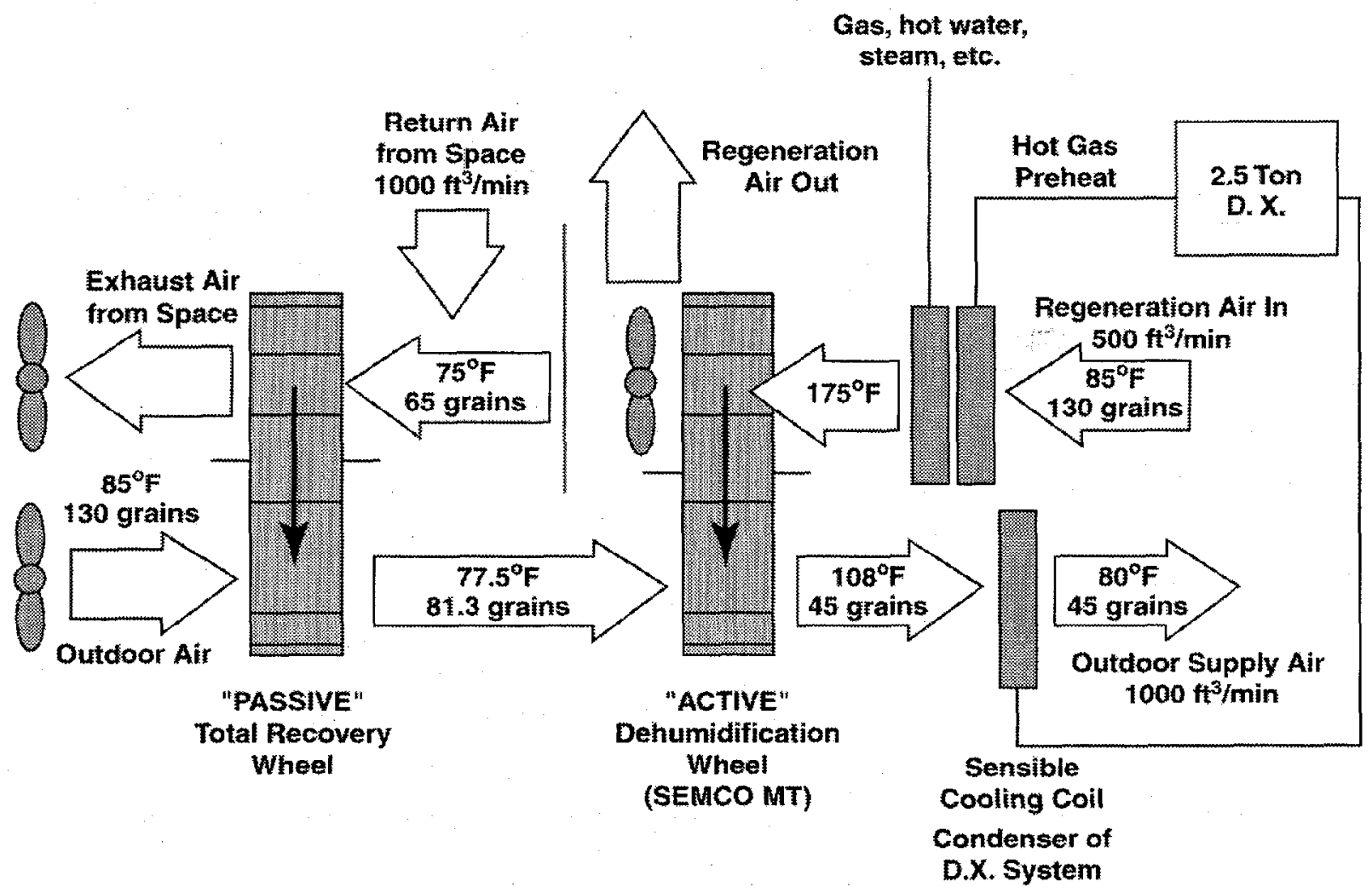

Fig. 4. Dehumidification-total energy recovery hybrid system.

\subsection{LIMITED ACTIVE DESICCANT SYSTEM OPTIONS MEET THE MARKET-DRIVEN NEEDS AND OPPORTUNITIES}

\subsubsection{Hospitals}

The dominant market driver for the use of active desiccant-based systems in hospitals is the need for humidity levels below those obtainable with conventional cooling approaches. This market would like a grain reduction of as much as 85 grains (from 120 grains down to 35 ) in order to maintain conditions in an operating room of $65^{\circ} \mathrm{F}$ and $50 \% \mathrm{RH}$, assuming a moderate internal latent load. For such applications, the systems shown in Figs. 4 and 6 are the most appropriate since they can easily supply the 35-grain air desired. The DBC approach shown schematically in Fig. 2 has a practical grain reduction limit of 60-65 grains and requires the use of evaporative coolers in the regeneration side, which is a serious concern for many hospital designers.

The dehumidification-only approach (Fig. 6) provides the most compact solution. The dehumidificationtotal energy recovery hybrid approach is the most energy-efficient while providing for significant heating season energy savings.

\subsubsection{Nursing Homes/Assisted Living}

The grain level required for nursing homes and assisted living facilities is obtainable with conventional cooling. Where a return air path is not available (i.e., corridor pressurization), the $\mathrm{DBC}$ approach is the most viable option (Fig. 1). It can provide the grain levels desired by these markets. When a return air 


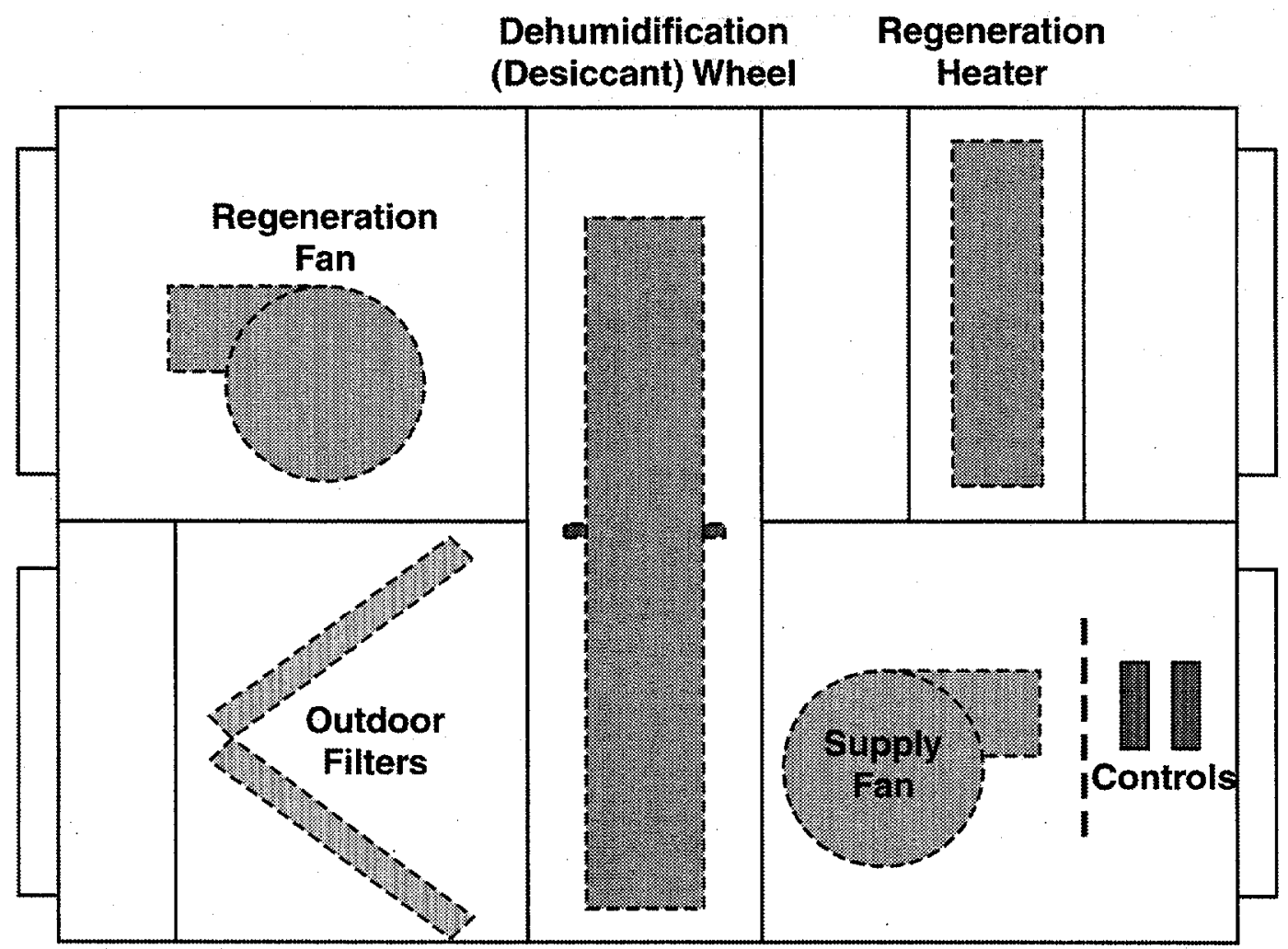

Fig. 5. Dehumidification-only approach (from Climate Changer modules).

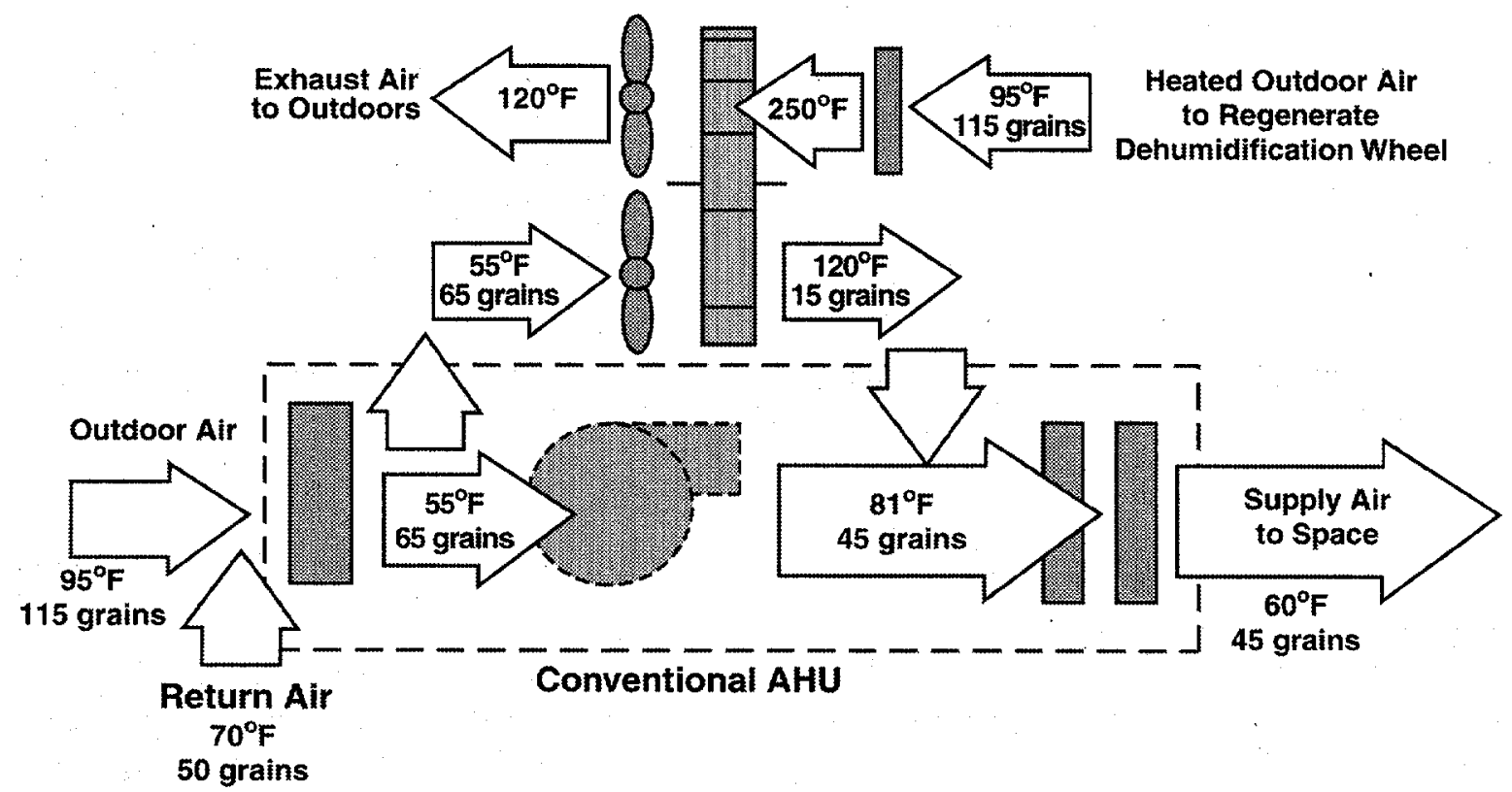

Fig. 6. Dehumidification-only assist to conventional cooling approach (from Climate Changer modules). 
path is available, the dehumidification-total energy recovery hybrid will likely provide the best solution because it offers winter time heat and humidity recovery, reduced system complexity, and elimination of the evaporative cooler.

If a hybrid combination of an active desiccant dehumidification module and a vapor-compression airconditioning rooftop product were available, it would likely be the preferred active desiccant choice for this market given the growth in the nursing home/assisted living industry and the price sensitivity and outdoor mounting requirements typical of assisted living facilities.

\subsubsection{Research Facilities}

Research facilities likely to be designed to incorporate an active desiccant approach are those where a significant quantity of exhaust air exists that is considered unavailable for recovery. As a result, such facilities will be a solid market for the traditional DBC approach (Fig. 1).

\subsubsection{Hotel/Dormitory}

The hotel/dormitory market fits criteria similar to those mentioned for nursing homes and assisted living facilitics. The likcly system choices are the same, although there also appears to be a market for the straight dehumidification approach to solve humidity problems in existing hotels located in hot and humid climates and in situations where the DBC system is too large or too costly. This market would also be well served by a Clarksville offering.

\subsubsection{Retail Facilities}

Retail facilities could benefit from each of the three active desiccant approaches discussed. If the facility is designed to conform to the ASHRAE standard recommendations, then there should be exhaust air available that can be used for the dehumidification-total recovery hybrid approach. If the outdoor air quantities are minimized, then the DBC approach located over the food area or a dehumidification module combined with a conventional packaged HVAC system is the best option.

\subsubsection{Schools}

If the benefits associated with dry cooling coils and year-round humidity control are embraced in the futurc by school designers, then the dehumidification-total energy recovery hybrid approach will provide an excellent solution for schools, as a return air path is almost always available. The ability to provide very dry air with this approach can complement a number of advanced system designs such as ice storage, super-cold systems, and gas engine-driven chiller designs. The sensible and latent heat recovery provided during the heating sẻason operation is a big plus and therefore favors this hybrid approach.

Table 3 summarizes the active desiccant approach most likely to be used by the identified markets.

Table 1 is a revision to Table 7 from the Phase 1 report. The Table 1 summary applies potential sales dollars to the information in Table 3 to provide a breakdown of estimated sales potential for each active desiccant approach by target market. The annual sales potential for active desiccant systems produced from Climate Changer modules and SEMCO dehumidification wheel modules is estimated at $\$ 82.5$ million, presenting a significant opportunity, though some part of this increased business would be at the expense of lost chiller sales in a separate business unit. 
Table 3. Active desiccant approach most likely to be used in targeted markets

\begin{tabular}{lccc}
\hline & $\begin{array}{c}\text { Traditional-desiccant based } \\
\text { cooling approach }\end{array}$ & $\begin{array}{c}\text { Dehumidification } \\
\text { recovery hybrid }\end{array}$ & total \\
Hospitals & $\mathrm{X}$ & $\mathrm{X}$ & $\mathrm{X}$ \\
Nursing homes & $\mathrm{X}$ & $\mathrm{X}$ & \\
Research facilities & $\mathrm{X}$ & $\mathrm{X}$ & $\mathrm{X}$ \\
Hotels/dormitories & $\mathrm{X}$ & $\mathrm{X}$ & $\mathrm{X}$ \\
Retail facilities & & $\mathrm{X}$ & $\mathrm{X}$ \\
Schools & & & \\
\hline
\end{tabular}

\subsection{KEY DESIGN OBJECTIVES DRIVING ACTIVE DESICCANT SYSTEM DEVELOPMENT (CONCLUSIONS OF MARKET RESEARCH)}

Both Phase 1 and subsequent marketing research have provided firm design direction to the active desiccant-based system choices presented in this report. SEMCO believes that following the market feedback will greatly increase the likelihood of widespread market acceptance of this technology. Some of the more important conclusions based on market research are as follows.

1. Unit first cost continues to be more important than optimizing energy efficiency. As with other mainstream HVAC equipment, the active desiccant product needs to be designed to provide the most "bang for the buck" in order to gain market acceptance. This translates into providing the most latent cooling output (pounds of moisture removed) for a given system first cost. This position is also supported by performance modeling, since most of the energy savings dollars associated with an active desiccant system come from reduced demand charges. As a result, optimizing COP is secondary to the ratio of $\$ /$ ton of latent cooling capacity.

2. As with passive desiccant systems, market acceptance will be based more on the equipment's ability to improve the quality of the indoor air (i.e., minimize pollutants and prohibit microbial activity), maintain the comfort of the building occupants, or meet an established code requirement than on a projected reduction in utility costs.

3. The primary function of active desiccant systems will be preconditioning the outdoor air delivered to buildings, linked with a design shift toward decoupling the outdoor air latent load with desiccant systems while using downsized conventional HVAC equipment to handle the internal sensible loads.

4. Size of the equipment will always be a major impediment to the use of active desiccant-based systems. The equipment will have to be designed to be as compact as possible while providing the required performance and serviceability.

5. Most opportunities for active desiccant systems involve systems sized for $10,000 \mathrm{cfm}$ or less (as is the case for other HVAC units). All desiccant systems are less competitive, from a first-cost perspective, the smaller they become (see Table 2). This conclusion reinforces conclusion 1 that a cost-effective design approach is critical for successful commercialization. 
6. The fact that low-cost hot water or steam is often available in the targeted markets significantly helps in justifying active desiccant systems. Therefore, it is desirable that the dehumidification wheel be capable of providing adequate performance at regeneration temperatures between 180 and $225^{\circ} \mathrm{F}$.

7. Minimizing the pressure loss through the active desiccant system is important because it has a significant impact on the cost of operation, as well as the installed fan horsepower, electrical components, and so on.

8. Evaporative coolers are not currently well received in the targeted markets. They are viewed as potential sources of microbial activity and odors and as being maintenance-intensive. Avoiding the use of these devices would be a plus for market acceptance.

Based on these market driven conclusions, the following "key design objective" was derived for the active desiccant system approaches:

Design the most compact active desiccant system(s) possible, maximizing the latent cooling (grain reduction) vs. cost ratio, utilizing $a$ dehumidification wheel capable of removing approximately 60 grains of moisture from outdoor air having a relative humidity of 80-90\% (dew point design data), and using a regeneration temperature in the range of 180 to $225^{\circ} \mathrm{F}$.

\subsection{SYSTEM DESIGN OBJECTIVES SET THE PERFORMANCE GOALS FOR THE ACTIVE DESICCANT WHEEL}

The performance, size and cost of the dehumidification wheel used for the active desiccant system approaches have the most significant impact on whether or not the stated "key design objective" is achieved. To reach the stated design objective for the active desiccant system, the desiccant dehumidification wheel must be designed to meet the following criteria:

- Operates at relatively high face velocities $(600$ to $700 \mathrm{ft} / \mathrm{min})$ to minimize the overall system size

- Limits pressure loss to $1 \mathrm{in.} w \mathrm{w}$ for both the supply and regeneration air

- Provides the stated grain reduction at the stated regeneration temperature range (60 grain reduction at the dew point design condition of $84^{\circ} \mathrm{F}$ and 130 grains)

- Operates in a flow configuration that matches the current Climate Changer product offering dimensional aspect ratios

- Is cost-effective to produce when commercialized in large quantities 
Additional desirable but less critical performance objectives include

- Requires minimal maintenance, resists plugging and performance degradation

- Optimizes latent cooling output/ regeneration energy input (latent COP)

- Co-sorbs airborne contaminants from the outdoor or recirculated airstream

These performance objectives parallel the criteria used by SEMCO in developing its current $1 \mathrm{M}$ composite active desiccant dehumidification wheel. The major exception is that the current product's desiccant adsorption parameters are optimized for a regeneration temperature range between approximately 250 and $300^{\circ} \mathrm{F}$. The SEMCO MT (moderate regeneration temperature) wheel tested as part of this program is being developed to fill the performance gap for the targeted (more moderate) regeneration temperature range (see Fig. 7).

The current SEMCO 1M wheel uses a desiccant surface that has an isotherm optimized for high regeneration temperatures. Based on SEMCO's in-house wheel testing thus far, the goal of removing 60 grains of moisture from outdoor air at the latent design condition $\left(85^{\circ} \mathrm{F}\right.$ and 130 grains) should be obtainable with a regeneration temperature in the range of $250^{\circ} \mathrm{F}$ once the casing, seals, purge, and spoke designs are optimized. This moisture removal target reflects the need to provide outdoor air at 70 grains $\left(57^{\circ} \mathrm{F}\right.$ dew point) during the $1 \%$ dew point design extreme.

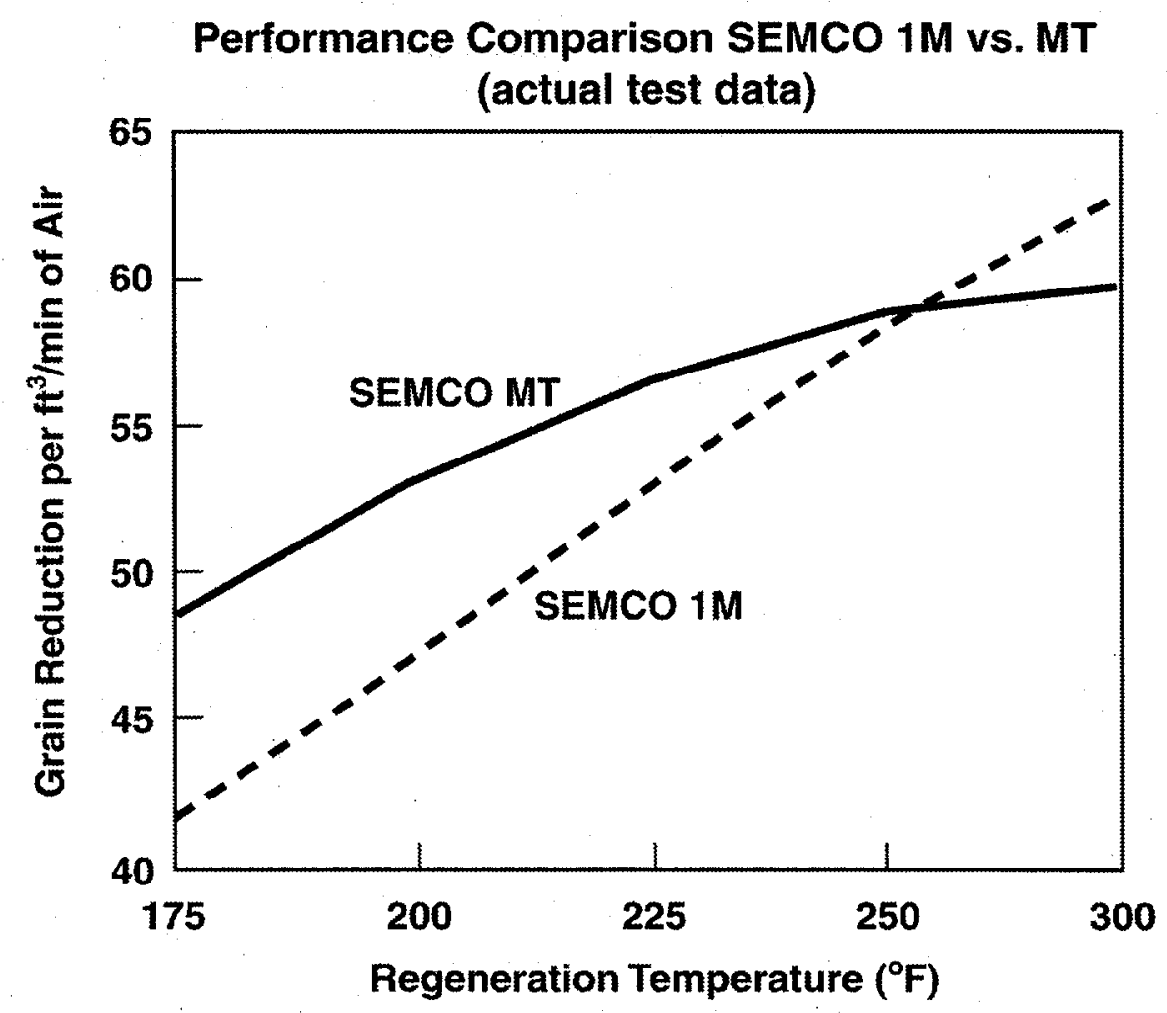

Fig. 7. Sample performance comparison: SEMCO 1M and SEMCO MT wheels with all conditions and operating parameters being equal. 
In addition to providing the targeted dehumidification capacity, this wheel has been specifically designed to co-sorb common indoor and outdoor airborne pollutants. Based on market fcedback, this feature is considered very beneficial by some of the markets targeted for active desiccant systems.

SEMCO has also developed and tested a second-generation wheel, type MT. The purpose for this new wheel is to respond to the need identified in the market analysis for an active desiccant wheel that can be regenerated more effectively at moderate regeneration temperatures (optimized for 200 to $225^{\circ} \mathrm{F}$ ). This wheel would be used where hot water, low-temperature steam, or waste heat is available.

It appears that this wheel may be slightly more costly to produce than the current SEMCO $1 \mathrm{M}$ wheel and may not have the same ability to remove targeted indoor and outdoor air pollutants as the $1 \mathrm{M}$ wheel. The initial results do look very promising and clearly justify further optimization of this product, which is under way.

As shown by Fig. 7, the performance advantage of the SEMCO MT wheel is clear compared with the 1M wheel at moderate regeneration temperatures. A significant improvement in moisture removal is recognized between approximately 150 and $225^{\circ} \mathrm{F}$ regeneration temperatures, with all other design parameters being equal.

Further testing of this new MT wheel is under way at SEMCO as part of the total system testing. A prototype wheel and cassette has been installed in the dehumidification-total energy recovery hybrid system built from Climate Changer modules (shown in Fig. 3, as well as in actual equipment pholographs attached to select copies of this report).

Since the MT wheel is still under development, the modeling and optimization presented in the next section are based on the current $1 \mathrm{M}$ technology. The performance data presented for the DBC approach are based upon the SEMCO 1M test data. The performance presented for the dehumidification-total energy hybrid approach uses the test data obtained thus far for the MT wheel. The performance shown for both of these wheels can and will be improved by further optimization. 


\section{PERFORMANCE MODELING}

\subsection{ACTIVE DESICCANT WHEEL OPTIMIZATION TO MEET TIE MARKET-DRIVEN PERFORMANCE CRITERIA AND STATED KEY DESIGN OBJECTIVE}

\subsubsection{Wheel Size and Process/Regeneration Area Percentages}

Although optimum performance may be provided with a process area to regeneration area split that is $75 / 25$, for example, fitting such a product into the Climate Changer modules (or any other system for that matter) would be difficult because of the airflow pattern that would result. The Climate Changer modules must be stacked to provide the two separate airstreams required for an active desiccant system (see Fig. 1 and the attached photographs).

Based on modeling, performance testing, and airflow patterns through the Climate Changer modules, an approximate 60 to $40 \%$ allocation of process to regeneration area appears to be the optimum selection. This configuration provides increased area to process the maximum quantity of outdoor (or recirculated) air while matching well with the size, aspect ratio, and flow pattern that exists within the Climate Changer product.

Table 4 clearly shows the importance of optimizing the dehumidification wheel for relatively high process face velocities. Note that at $600 \mathrm{ft} / \mathrm{min}$, the process flow volume through the dehumidification wheel represents on average $82 \%$ of the current design capacity of the Climate Changer modules. At $650 \mathrm{ft} / \mathrm{min}$, the resulting flow would be $90 \%$.

In contrast, operating at a face velocity of $400 \mathrm{ft} / \mathrm{min}$, even for a wheel with a $60 / 40$ split, would only use

Table 4. Comparison of Climate Changer design airflow rates with dehumidification wheel geometry and face velocity

(Using SEMCO SMCC wheel diameters)

\begin{tabular}{|c|c|c|c|c|c|c|}
\hline & \multicolumn{6}{|c|}{ Trane Climate Changer model number } \\
\hline & $\mathrm{CC}-6$ & $\mathrm{CC}-10$ & CC-14 & $\mathrm{CC}-21$ & $\mathrm{CC}-30$ & $\mathrm{CC}-40$ \\
\hline Design airflow for Climate changer (cfm) & 2,930 & 4,820 & 7,110 & 10,390 & 14,505 & 19,650 \\
\hline Design flow SMCC DH ${ }^{a}$ at $600 \mathrm{ft} / \mathrm{min}(\mathrm{cfm})$ & 2,520 & 3,744 & 6,048 & 8,424 & 12,096 & 16,128 \\
\hline Percent optimum capacity used & $80 \%$ & $78 \%$ & $85 \%$ & $81 \%$ & $83 \%$ & $82 \%$ \\
\hline Design flow SMCC DH ${ }^{a}$ at $500 \mathrm{ft} / \mathrm{min}(\mathrm{cfm})$ & 2,100 & 3,120 & 5,040 & 7,020 & 10,080 & 13,440 \\
\hline Percent optimum capacity used & $72 \%$ & $65 \%$ & $71 \%$ & $68 \%$ & $69 \%$ & $68 \%$ \\
\hline Design flow SMCC DH ${ }^{a}$ at $400 \mathrm{ft} / \mathrm{min}(\mathrm{cfm})$ & 1,680 & 2,496 & 4,032 & 5,616 & 8,064 & 10,752 \\
\hline Percent optimum capacity used & $57 \%$ & $52 \%$ & $57 \%$ & $54 \%$ & $56 \%$ & $55 \%$ \\
\hline
\end{tabular}

${ }^{a}$ SMCC DH wheel is a modification to the standard SEMCO SMCC total energy wheel that has a 50/50 split between the exhaust and the outdoor air halves of the wheel. THe SMCC DH wheel has $60 \%$ of the area in the outdoor air portion and $40 \%$ of the wheel area in the regeneration air portion. 
approximately $55 \%$ of the capacity of the Climate Change modules. Since the cost of the final system is a function of the size of the Climate Changer modules used, and not of the airflow quantity processed, operating the system at reduced capacity would significantly increase the cost/ton of latent cooling ratio, one of the primary optimization goals based on market feedback.

For example, a commercialized DBC system produced with conventional Climate Changer modules, using a desiccant wheel with a 60/40 split operated at $600 \mathrm{ft} / \mathrm{min}$ and processing $2500 \mathrm{cfm}$, would have a projected selling price of approximately $\$ 5.60 / \mathrm{cfm}$. If the wheel were operated at $400 \mathrm{ft} / \mathrm{min}$ in lieu of 600 , the selling price would increase by $61 \%$ to approximately $\$ 9 / \mathrm{cfm}$. Higher face velocities result in larger pressure drops across components and correspondingly more fan power.

As a result, optimizing for a high face velocity through the desiccant dehumidification wheel becomes one of the most important criteria impacting successful commercialization. Process face velocity significantly impacts both the overall system cost and size, two of the most important optimization parameters based on market feedback.

Therefore, one of the primary design goals for the SEMCO dehumidification wheel development is to provide the 60 grain moisture reduction with a process face velocity of approximately $600 \mathrm{ft} / \mathrm{min}$ while maintaining the pressure loss through the process and regeneration airstreams at a maximum of $1 \mathrm{in.} \mathrm{wg}$ each.

\subsubsection{Optimizing Wheel Speed and Managing Heat Carryover}

A significant amount of testing has been completed to optimize the wheel speed to provide the maximum moisture removal (i.e., latent tons) as a function of wheel face velocity, incoming grain content, regeneration temperature, and so on. At the targeted high process face velocity, as expected, an increased wheel speed is requircd to obtain the desired grain depression. Naturally, the higher wheel speed results in higher carryover heat than desired if minimizing supply outlet temperature is considered a key optimization parameter. Heat carryover is a function of wheel speed, non-desiccant mass fraction, desiccant heat of adsorption, and other factors.

Heat carryover in an active desiccant system is interesting in that it has both a negative and a positive effect. The negative effect is that the overall cooling capacity of an active desiccant-based cooling system is reduced as the carryover heat is increased. A GRI report covers this issue quite well and concludes that high heat of adsorption (carryover heat) typically decreases the cooling capacity of a DBC system (Collier 1988, p. 46).

On the other hand, since the DBC approach uses a very efficient sensible-only recovery wheel to capture this carryover heat to preheat the air entering the regeneration source, high heat carryover actually increases energy efficiency, raising the system COP (Collier 1988).

Figures 8 and 9 show the relative impact of increased heat carryover in a DBC system configuration. Figure 8 shows a condition that represents the SEMCO $1 \mathrm{M}$ wheel with increased heat carryover. Figure 9 shows what the relative total cooling tons, latent cooling tons, and COP would be for an identical system assuming a significant reduction in carryover heat $\left(20^{\circ} \mathrm{F}\right)$, with all other design parameters being equal. 


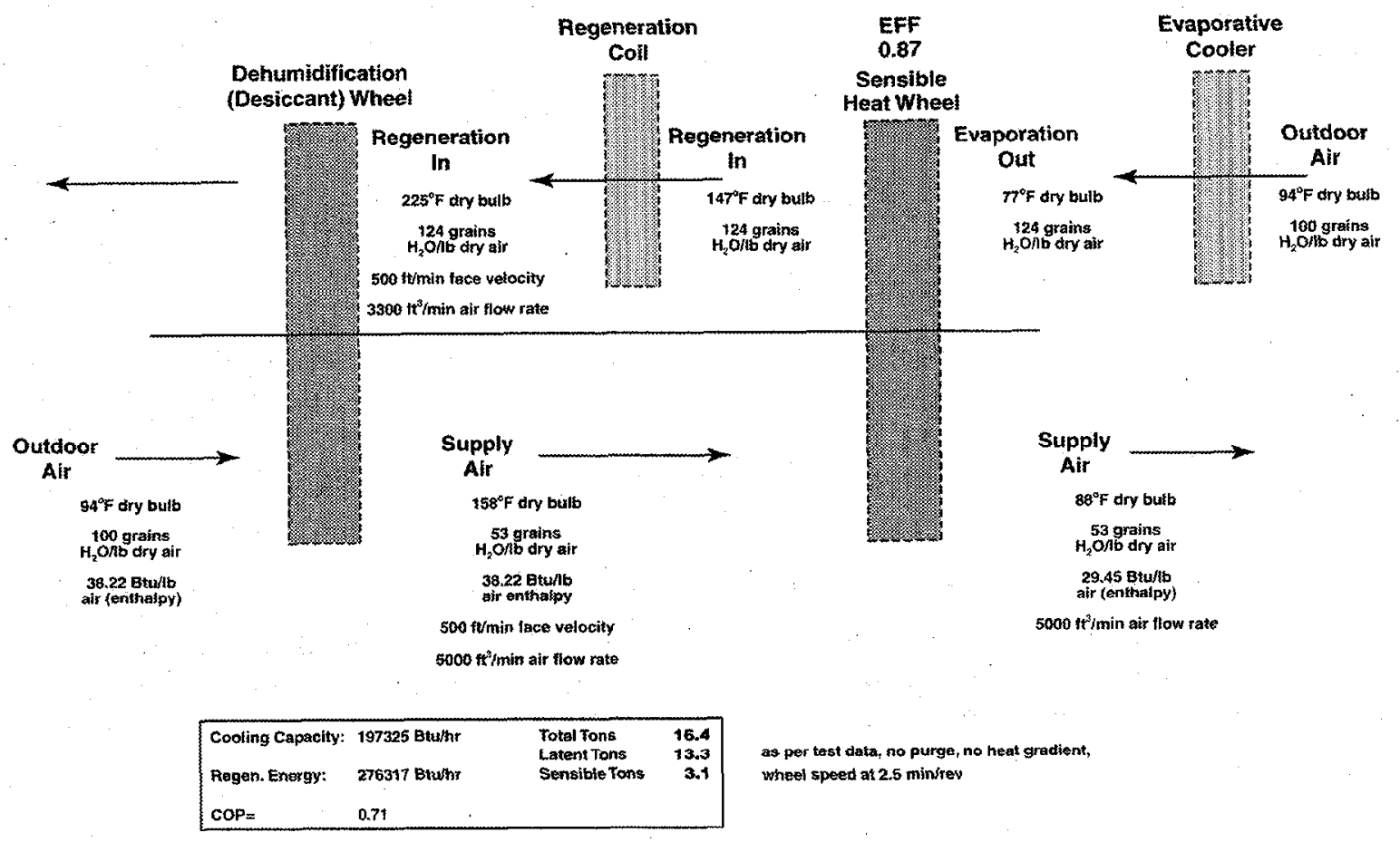

Fig. 8. High heat carry-over DBC flow diagram

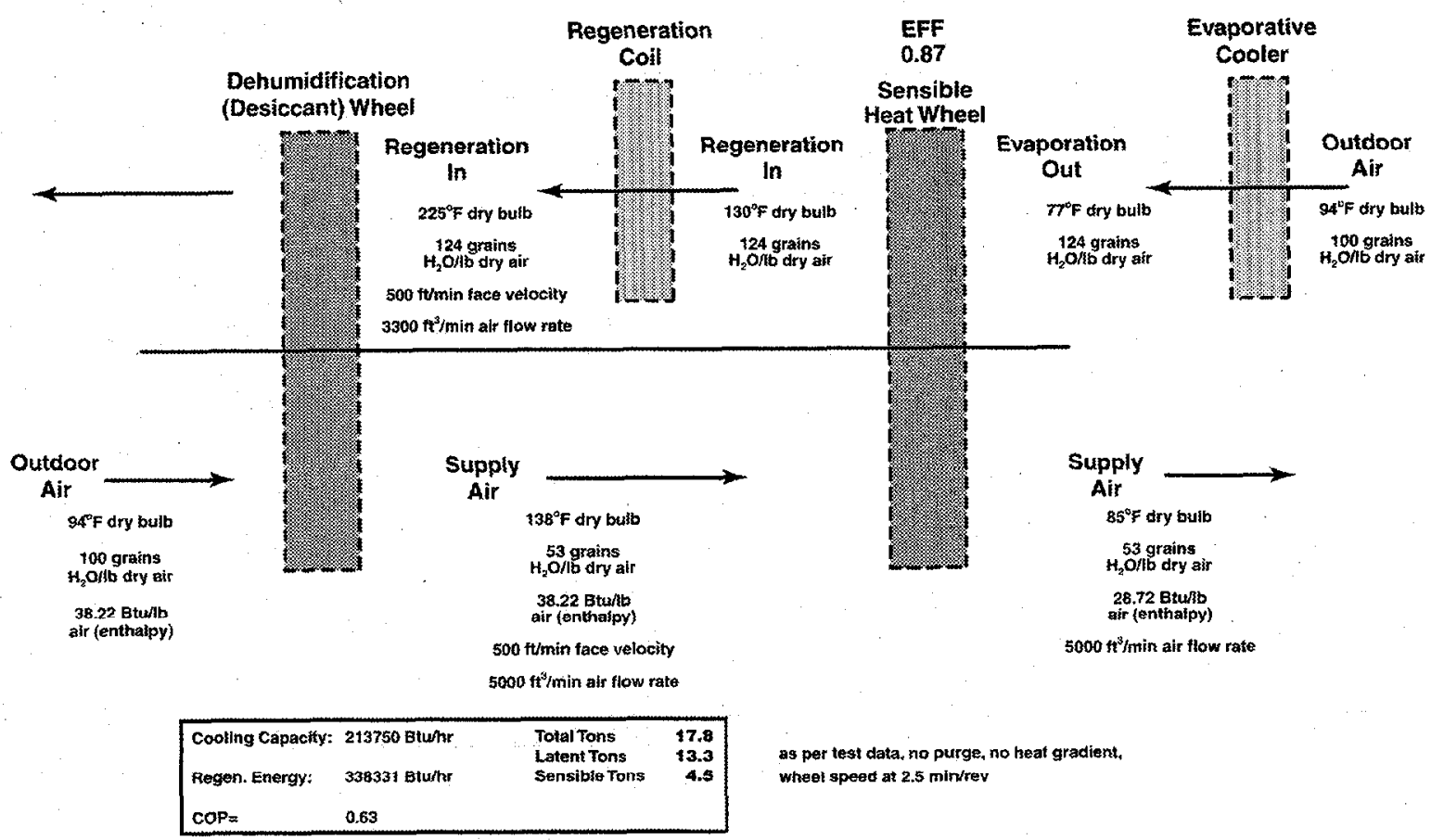

Fig. 9. Reduced heat carry-over DBC flow diagram. 
Note the following:

- the most important parameter, latent cooling capacity, is identical

- the next most important factor, $\mathrm{COP}$, is increased by $13 \%$ with the high carryover heat

- the least important factor, sensible cooling tons, is decreased

Note that the difference in the supply air temperature leaving the sensible wheel in Figs. 8 and 9 is only $3^{\circ} \mathrm{F}$ despite the significant $20^{\circ} \mathrm{F}$ difference in the air temperature leaving the dehumidification wheel (this is increased to only $3.8^{\circ} \mathrm{F}$ when the sensible wheel efficiency drops to $80 \%$ ). Fan heat in a system of this type would be on the order of 2 to $5^{\circ} \mathrm{F}$. In short, the net impact on sensible cooling performance of the $20^{\circ} \mathrm{F}$ increase in heat carryover is small and on a par with the impact of supply side fan heat.

As a result, the positive impact on COP seems to outweigh the negative impact of reduced sensible cooling load. It can therefore be concluded that the higher heat carryover associated with operating at higher process face velocities is not a significant negative and may, in fact, be a positive in justifying the active desiccant technology based on operating efficiency.

\subsubsection{Purge Section Impact}

Modeling has also shown that the active desiccant system benefits from the adaptation of a purge section to the dehumidification wheel cassette. This has been confirmed by SEMCO through testing and will be optimized further as part of the final system testing. A purge section uses unconditioned outdoor air to push some of the carryover heat (and associated high humidity) into the regeneration airstream, thereby increasing dehumidification performance, reducing the supply air outlet temperature, and/or reducing regeneration energy.

Figure 10 shows the same system configuration as in Fig. 8 (high heat carryover) but uses a $10^{\circ} \mathrm{F}$ purge angle to reduce heat carryover and regeneration energy. The performance shown in this example is based on modeling that will be confirmed when system testing is complete. Note that if the latent cooling is kept the same between examples 1 and 3, the COP is increased from 0.71 to 0.84 , and the sensible cooling is also increased slightly from 3.1 to 3.6 tons. Figure 10 could have been configured to show an increase in latent cooling capacity (grain reduction), which is the most important advantage for the same energy input shown for Fig. 8 .

As a result of these findings, it is expected that the use of a purge will provide an increase in latent capacity of approximately $5-10 \%$, and it will likely be a standard feature in active desiccant systems optimized to meet the key design objective previously stated.

\subsubsection{Benefit of Using the Heat Gradient of the Sensible Wheel}

The improvement in COP associated with increased carryover heat becomes even more pronounced when the heat gradient leaving the sensible recovery wheel is taken advantage of. The higher temperature leaving the desiccant wheel translates into a higher average temperature entering the regeneration heater (assuming that only a fraction of the air leaving the sensible wheel on the regeneration air side is used for regeneration). 


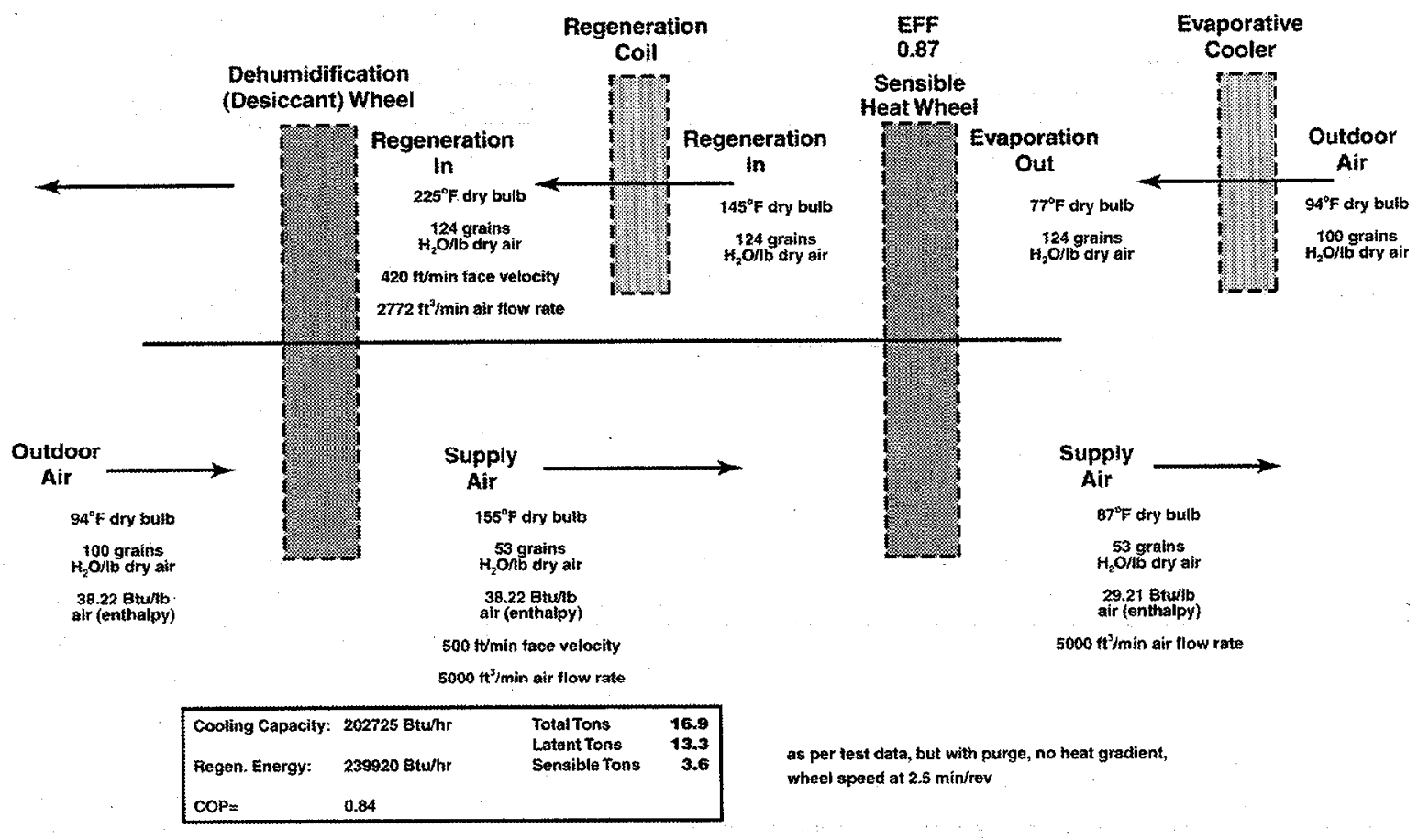

Fig. 10. High heat carry-over with purge DBC flow diagram.

As shown in Fig. 11, the air leaving the first half of the sensible wheel on the regeneration inlet side is increased from $145^{\circ} \mathrm{F}$ (example 3) to $150^{\circ} \mathrm{F}$. This modeled gradient trend has been confirmed by testing conducted at SEMCO. The use of this heat gradient has the potential of further increasing the system COP from the 0.84 value shown in example 3 to 0.9 as shown in Fig. 11.

\subsection{REVISIONS OF MODELING USING NEW DESICCANT WHEEL PERFORMANCE DATA (TESTING COMPLETED IN TASKS 2 AND 6)}

\subsubsection{Improved Operating Costs of DBC and DH/ER Hybrid Approaches}

The SEMCO Phase 1 report included a summary of many computer-generated estimates of operating costs for the various specialized air handling units investigated. The energy analyses completed for the active desiccant systems were based on preliminary test data measured by SEMCO on its 1M wheel technology. This program has provided an opportunity to improve upon this core technology that has resulted in enhanced performance in the wheel itself.

Figures A.1 and A.2 in Appendix A show the energy analyses completed for the DBC and the dehumidification-total energy recovery hybrid configurations as part of Phase 1 work based on the previous wheel performance parameters. Figures A.3 and A.4 show the same analyses but have been modified to reflect the current performance associated with the SEMCO $1 \mathrm{M}$ wheel.

As a comparison of Figs. A.1 through A.4 shows, the improved performance for the dehumidification wheel reduced the operating cost of the modeled DBC system by approximately $5 \%$ and the cost of the modeled dehumidification-total energy recovery hybrid by approximately $4 \%$. 


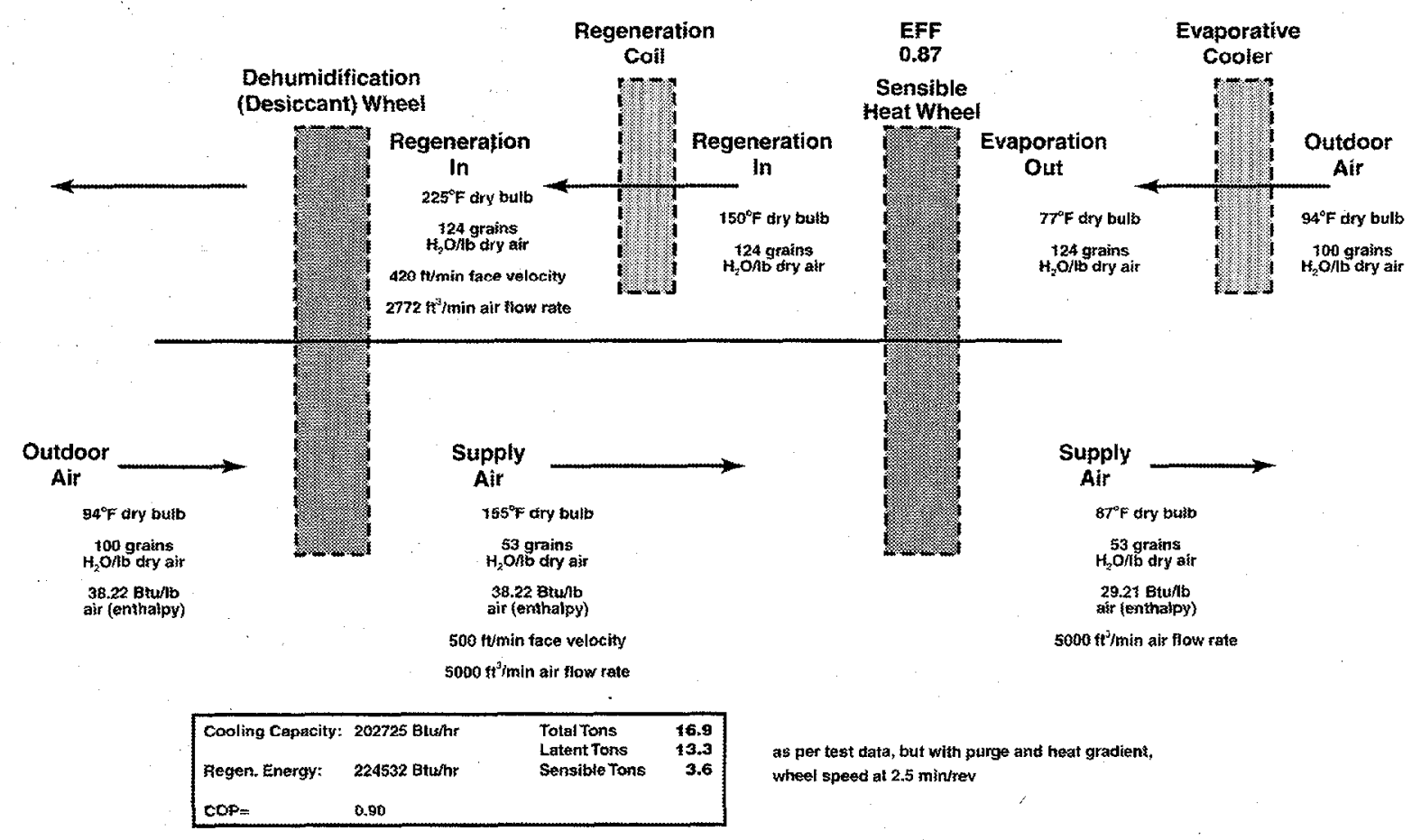

Fig. 11. High heat carry-over with purge and heat gradient.

Table 5 is a revision to Table 4 in an earlier marketing report. The payback periods for the three active desiccant-based system approaches have been modified to reflect the actual wheel performance provided by the SEMCO 1M wheel. The results of this analysis for active desiccant systems is quite favorable; a payback is very short or immediate for all systems with a capacity of $7500 \mathrm{cfm}$ or greater, and approximately 2 years for systems in the $2500-\mathrm{cm}$ range. It is important to point out that these payback periods are strongly influenced by the cost of energy, as well as the cost of installed chiller and cooling tower capacity (assumed to be $\$ 500 /$ ton for this analysis).

\subsubsection{Impact of the New ASHRAE Dew Point Design Data: Good and Bad for Active Desiccant Systems}

Table 6 shows the difference between dry bulb/mean coincident wet bulb design conditions and the new dew point/mean coincident dry bulb design data recently published in the 1997 ASHRAE Fundamentals (ASHRAE). This table, which compares the data for six cities, shows that the dew point design data result in much higher latent loads as well as total cooling loads associated with the outdoor air. This is clearly a plus for any system designed spccifically to manage latent loads in outdoor air volumes. As a result, this is a plus for active desiccant systems.

Table 7 summarizes energy analyses completed for the seven specialized air handling units investigated in the earlier report. The operating costs associated with the active desiccant systems have been updated since presented in the Phase 1 report to reflect the current test data for the SEMCO dehumidification wheel. This analysis paints a positive picture for the active desiccant approach in that the cost of operation decreases by an average of $6 \%$ while the cost of the conventional approaches actually increases by the same amount. As shown, the cost of operating passive systems remains the same independent of the design conditions used. 
Table 5. Simple payback of various preconditioning approaches at different airflow capacities

\begin{tabular}{|c|c|c|c|}
\hline Preconditioning system approach & $\begin{array}{c}2,500 \mathrm{cfm} \\
\left(\text { simple payback in months }{ }^{a}\right)\end{array}$ & $\begin{array}{c}7,500 \mathrm{cfm} \\
\left(\text { simple payback in months }{ }^{a}\right)\end{array}$ & $\begin{array}{c}20,000 \mathrm{cfm} \\
\left(\text { simple payback in months }{ }^{a}\right)\end{array}$ \\
\hline Conventional cooling w/reheat & NA & NA & NA \\
\hline Conventional cooling w/run around recovery & $\begin{array}{c}0.3 \text { months } \\
\text { (\$2009/yr in energy savings) }\end{array}$ & $\begin{array}{c}\text { (\$200 first cost savings) } \\
\text { Immediate } \\
\text { (\$6028/yr in energy savings) }\end{array}$ & $\begin{array}{c}0.2 \text { months } \\
\text { (\$16074/yr in energy savings) }\end{array}$ \\
\hline Total energy wheel w/cooling and reheat & $\begin{array}{c}5 \text { months } \\
\text { (\$1892/yr in energy savings) }\end{array}$ & $\begin{array}{l}\text { (\$1850 first cost savings) } \\
\text { Immediate } \\
\text { (\$5676/yr in energy savings) }\end{array}$ & $\begin{array}{c}\text { (\$10400 first cost savings) } \\
\text { Immediate } \\
(\$ 15136 / y r \text { in energy savings) }\end{array}$ \\
\hline Dual wheel total energy recovery & $\begin{array}{c}9 \text { months } \\
\text { (\$3907/yr in energy savings) }\end{array}$ & $\begin{array}{c}\text { (\$350 first cost savings) } \\
\text { Immediate } \\
\text { (\$11720/yr in energy savings) }\end{array}$ & $\begin{array}{c}\text { (\$11050 first cost savings) } \\
\text { Immediate } \\
\text { (\$31253/yr in energy savings) }\end{array}$ \\
\hline Dual wheel desiccant based (DBC) w/post cooling & $\begin{array}{l}20 \text { months } \\
\text { (\$2988/yr in energy savings) }\end{array}$ & $\begin{array}{c}0.5 \text { months } \\
\text { (\$8960/yr in energy savings) }\end{array}$ & $\begin{array}{l}\text { (\$11900 first cost savings) } \\
\text { Immediate } \\
\text { (\$23900/yr in energy savings) }\end{array}$ \\
\hline Desiccant dehumidification-total recovery hybrid & $\begin{array}{c}27 \text { months } \\
\text { (\$3188/yr in energy savings) }\end{array}$ & $\begin{array}{c}5 \text { months } \\
\text { (\$9565/yr in energy savings) }\end{array}$ & $\begin{array}{c}\text { (\$2350 first cost savings) } \\
\text { Immediatc } \\
\text { (\$25500/yr in energy savings) }\end{array}$ \\
\hline Dual wheel DBC-Lotal recovery hybrid & $\begin{array}{c}27 \text { months } \\
\text { (\$4362/yr in energy savings) }\end{array}$ & $\begin{array}{c}6.5 \text { months } \\
(\$ 13080 / \mathrm{yr} \text { in energy savings) }\end{array}$ & $\begin{array}{c}\text { Immediate } \\
\text { (\$34895/yr in energy savings) }\end{array}$ \\
\hline
\end{tabular}

${ }^{a}$ The simple payback compares the various preconditioning approaches with the conventional cooling with reheat approach. All dimensions assume the use of Trane Climate Changer modules and SEMCO wheel modules. All sales prices are estimates of the market price using Climate Changer modules. Allantia weather data and 1994 local energy costs are used for this comparison. The energy savings are based on continuous operation and chiller/cooling tower cost of $\$ 500 /$ ton. The conventional cooling with run around uses the plate heat exchanger currently offered by Trane. 
Table 6. Comparison of humidity design data: dry bulb and mean coincident wet bulb (MCWB) and mean coincident dry bulk (MCDB) data vs dew point design

( $2 \%$ design condition)

\begin{tabular}{|c|c|c|c|c|c|c|c|c|}
\hline \multirow[b]{2}{*}{ City } & \multicolumn{4}{|c|}{ Dry bulb, MCWB } & \multicolumn{4}{|c|}{ Dew point, MCDB } \\
\hline & $\begin{array}{c}\text { Dry bulb } \\
\left({ }^{\circ} \mathrm{F}\right)\end{array}$ & $\begin{array}{c}\text { Wet bulb } \\
\left({ }^{\circ} \mathrm{F}\right)\end{array}$ & $\begin{array}{c}\text { Grains } \\
\left(\mathrm{H}_{2} \mathrm{O} / \mathrm{lb} \text { air }\right)\end{array}$ & $\begin{array}{l}\text { Enthalpy } \\
\text { (Btu/lb air) }\end{array}$ & $\begin{array}{c}\text { Dew point } \\
\left({ }^{\circ} \mathrm{F}\right)\end{array}$ & $\begin{array}{c}\text { Dry bulb } \\
\left({ }^{\circ} \mathrm{F}\right)\end{array}$ & $\begin{array}{c}\text { Grains } \\
\left(\mathrm{H}_{2} \mathrm{O} / \mathrm{lb} \text { air }\right)\end{array}$ & $\begin{array}{l}\text { Enthalpy } \\
\text { (Btu/lb air) }\end{array}$ \\
\hline Atlanta & 88 & 73 & 109 & 37.3 & 72 & 80 & 123 & 38.5 \\
\hline Houston & 92 & 77 & 117 & 40.5 & 76 & 83 & 137 & 41.4 \\
\hline Los Angeles & 78 & 64 & 93 & 29.3 & 65 & 72 & 93 & 31.8 \\
\hline Minneapolis & 85 & 70 & 90 & 34.5 & 69 & 79 & 110 & 36.2 \\
\hline New York & 86 & 72 & 97 & 35.8 & 71 & 80 & 116 & 37.3 \\
\hline Orlando & 92 & 76 & 110 & 39.4 & 76 & 81 & 136 & 40.8 \\
\hline
\end{tabular}

Source: ASHRAE Fundamentals 1997.

The downside for active desiccant systems as a result of the new dew point weather data is reduced traditional COP values (total cooling provided/regeneration energy input) and increased post-cooling requirements (as a result of higher supply air temperatures after the dehumidification wheel).

Figures A.5 and A.6 provide schematic examples of typical active desiccant system performance for both the traditional dry bulb BIN design condition and the new dew point design condition. Note that since the dew point design condition represents a much higher absolute humidity level, more moisture needs to be removed. The greater the grain reduction required, the greater the regeneration energy required and the greater the heat of adsorption. The result is a much higher temperature leaving the dehumidification wheel than would be associated with the dry bulb design condition (Fig. A.5).

At the same time that the dew point design condition produces a much higher temperature after the dehumidification wheel, it unfortunately also provides less post-cooling capacity because the outdoor air condition is near saturation, rendering the indirect evaporative cooling side of the system ineffective (see Fig. A.6).

As shown by Fig. A.6, the performance of a DBC cycle operated at the dew point design condition can result in negative sensible cooling tons and therefore in increased post-cooling requirements. The result is also much reduced traditional COP values and total cooling output. On the other hand, the latent cooling tons (the most important criterion) increases significantly over the level obtained at the dry bulb design condition.

Figures A.7 and A.8 show a similar trend for the dehumidification-total energy recovery hybrid approach. The higher humidity content associated with the dew point design condition results in much higher latent cooling output while reducing traditional COP values and increasing the post-cooling energy required. 
Table 7. Impact of new ASHRAE weather data (wet bulb BINS, corresponding dry bulb)

\begin{tabular}{lccc}
\hline $\begin{array}{c}\text { Preconditioning system } \\
\text { approach }\end{array}$ & $\begin{array}{c}\text { Annual energy cost estimate for } \\
\text { a 20,000 cfm system located in } \\
\text { Atlanta based on Air Force } \\
\text { weather data } \\
\text { (current dry bulb BIN method) }\end{array}$ & $\begin{array}{c}\text { Annual energy cost estimate for } \\
\text { atlanta based on revised } \\
\text { ASHRAE data } \\
\text { (new wet bulb BIN method) }\end{array}$ & $\begin{array}{c}\text { Percent change } \\
\text { (\%) }\end{array}$ \\
\hline $\begin{array}{l}\text { Conventional cooling } \\
\text { w/reheat }\end{array}$ & $\$ 58,180$ & $\$ 61,597$ & 6 \\
$\begin{array}{l}\text { Conventional cooling w/run } \\
\text { around recovery }\end{array}$ & $\$ 44,020$ & $\$ 46,205$ & 5 \\
$\begin{array}{l}\text { Total energy wheel } \\
\text { w/cooling and reheat }\end{array}$ & $\$ 43,046$ & $\$ 43,390$ & 0.90 \\
$\begin{array}{l}\text { Dual wheel total energy } \\
\text { recovery }\end{array}$ & $\$ 26,928$ & $\$ 27,060$ & 0.50 \\
$\begin{array}{l}\text { Duel wheel desiccant based } \\
\text { (DBC) w/post cooling }\end{array}$ & $\$ 33,689$ & $\$ 30,994$ & -8 \\
$\begin{array}{l}\text { Desiccant } \\
\text { dehumidification- total } \\
\text { recovery hybrid }\end{array}$ & $\$ 32,066$ & & -6 \\
$\begin{array}{l}\text { Dual wheel DBC-total } \\
\text { recovery hybrid }\end{array}$ & & $\$ 30,142$ & \\
\hline
\end{tabular}

${ }^{a}$ Assumptions:

- Reflects the use of a favorable gas cooling rate of $\$ 0.35 /$ therm.

- Wet bulk BIN data are from ASHRAE.

- Units are assumed to operate continuously.

- Electricity is $\$ 0.06 / \mathrm{kWh}$ and $\$ 8.00 / \mathrm{kW}$ demand.

- Gas at $\$ 0.48 /$ therm for all but DBC summer time use. A $78 \%$ boiler efficiency is assume.

- Location is Atlanta.

What is clear from this analysis is that the dew point design conditions offer the advantage of increased latent output but also result in increased supply air temperatures off the active desiccant system, increasing the need for post-cooling. Post-cooling cannot be eliminated completely if a temperature of 70 to $80^{\circ} \mathrm{F}$ (room neutral temperature) is desired. The good news is, based once again on market analysis, the latent output is far more important than the traditional COP value (operating efficiency). In addition, the post-cooling energy is on a par with the energy required for reheating the conventional cooling approach. 


\section{CONCLUSIONS}

\subsection{COMPARING SYSTEMS BASED ON LATENT AIR CONDITIONING DELIVERED}

The success of the introduction of any active desiccant product will depend upon the importance placed by the design community on improved humidity control, the acceptance of ASHRAE 62-89, and a paradigm shift toward decoupling the latent and sensible loads. As a result, the success of a specific active desiccant approach will be directly linked to its ability to perform as the most effective "latent air conditioning" alternative. Such a product will be applied to handle the latent load associated with the outdoor air alone or the outdoor air combined with the space latent load.

Given the intended use of this technology, to provide latent air conditioning, it appears to be inappropriate to compare it with other, more conventional approaches based on total cooling capacity. For example, a system designed to provide total cooling (sensible and latent) should be rated based on total cooling capacity, and a COP (or EER) should be based upon the ratio of total cooling to energy input. Likewise, it seems logical that a latent air conditioning system should be compared in a corresponding fashion, with a rating based on tons of latent cooling capacity and a COP measurement based on latent cooling output/energy input.

Tables 8, 9, and 10 compare a conventional overcooling-reheat approach, a DBC approach, and a dehumidification-total energy recovery hybrid approach at both the dry bulb BIN and the dew point design conditions. These figures show both the total cooling capacity and latent cooling capacity resulting from each approach.

When these systems are compared as latent air conditioning systems, the advantage of applying a commercialized active desiccant approach such as that built from Climate Changer modules becomes obvious. In short, the first-cost advantage for the conventional overcooling-reheat approach disappears when systems are compared based on latent output, the primary purpose for the equipment. Also, when the reheating required by the conventional cooling approach is compared with the post-cooling required by the active desiccant approaches, it is clear that the energy required is similar at the design condition. At part-load conditions, the active desiccant systems have the advantage since the desiccant system's post-cooling energy decreases rapidly as the outdoor air conditions become less extreme, while the reheating energy required by the conventional system remains constant until the outdoor air humidity content falls below that delivered to the space. This seemingly contradictory result occurs because desiccated air is heated by the drying process, and additional sensible cooling is required to lower its temperature to starting conditions.

Note that even at the high-humidity condition associated with the dew point design condition (Table 8), the conventional cooling approach only provides 26 tons of latent cooling with a 47 ton total cooling input (at $7500 \mathrm{cfm}$ ). The DBC approach (Table 9) provides the same 26 tons of latent cooling but provides only 21 tons of total cooling. When first cost is based on \$/total tons provided, the conventional approach looks far less expensive. When the systems are compared based on latent output, the appropriate method of comparison since it reflects the purpose of the system, the active DBC and the conventional cooling approach are essentially the same. Once the operating cost is factored into the equation, the active approach often provides the best return on investment. 
Table 8. Conventional overcooling with reheat preconditioning approach

\begin{tabular}{|c|c|c|c|c|c|c|c|}
\hline \multicolumn{8}{|c|}{ Outdoor air condition: $94^{\circ} \mathrm{F}$ and 100 grains (typical dry bulb design condition) supplied at 53 grains and space neutral temperature } \\
\hline $\begin{array}{l}\text { Outdoor } \\
\text { air volume } \\
\text { (SCFM) }\end{array}$ & $\begin{array}{c}\text { Total cooling } \\
\text { tons } \\
(1)\end{array}$ & $\begin{array}{l}\text { Total } \\
\text { cooling } \\
\text { COP }\end{array}$ & $\begin{array}{l}\text { Latent load } \\
\text { cooling tons } \\
\text { (2) }\end{array}$ & $\begin{array}{l}\text { Latent } \\
\text { load } \\
\text { COP }\end{array}$ & $\begin{array}{l}\text { Estimated sales price } \\
\text { Climate Changer modules } \\
\text { (3) }\end{array}$ & $\begin{array}{l}\text { Cost per ton } \\
\text { latent removal }\end{array}$ & $\begin{array}{l}\text { Comments } \\
\text { (4) }\end{array}$ \\
\hline 2,500 & 16.4 & NA & 6.7 & NA & $\$ 10,400$ & $\$ 1,552$ & $\begin{array}{l}\text { Requires an additional } 54,000 \text { BTUs of reheat energy to reach the } \\
\text { desired space neutral lower limit of } 70^{\circ} \mathrm{F}\end{array}$ \\
\hline 7,500 & 49.2 & NA & 20.1 & NA & $\$ 31,700$ & $\$ 1,577$ & $\begin{array}{l}\text { Requires an additional } 162,000 \mathrm{BTUs} \text { of reheat energy to reach the } \\
\text { desired space neutral lower limit of } 70^{\circ} \mathrm{F}\end{array}$ \\
\hline 20,000 & 131 & NA & 53.6 & NA & $\$ 82,200$ & $\$ 1,534$ & $\begin{array}{l}\text { Requires an additional } 432,000 \text { BTUs of reheat energy to reach the } \\
\text { desired space neutral lower limit of } 70^{\circ} \mathrm{F}\end{array}$ \\
\hline \multicolumn{8}{|c|}{$\begin{array}{l}\text { Notes: 1. Total tons based upon conditioning outdoor air from } 94^{\circ} \mathrm{F} \text { and } 100 \text { grains to } 51^{\circ} \mathrm{F} \text { and } 53 \text { grains. } \\
\text { 2. Latent tons based upon reducing the humidity content of the outdoor air from } 100 \text { grains to } 53 \text { grains. } \\
\text { 3. Estimated selling price of equipment based upon Climate Changer module pricing in } 1996 \text { dollars and required chiller tonnage at } \$ 500 / \text { ton. } \\
\text { 4. As per the Phase } 1 \text { work, it is assumed that the preconditioned outdoor air needs to be provided dehumidified and at a space ncutral temperaturc. This conventional } \\
\text { overcooling-reheating approach requires the reheat energy shown in this column to reach the targeted } 70-80^{\circ} \mathrm{F} \text { delivery condition. }\end{array}$} \\
\hline \multicolumn{8}{|c|}{ Outdoor air condition: $84^{\circ} \mathrm{F}$ and 130 grains (typical dew point design condition) supplied at 70 grains and space neutral temperature } \\
\hline $\begin{array}{l}\text { Outdoor } \\
\text { air volume } \\
\text { (SCFM) }\end{array}$ & $\begin{array}{c}\text { Total cooling } \\
\text { tons } \\
\text { (1) }\end{array}$ & $\begin{array}{l}\text { Total } \\
\text { cooling } \\
\text { COP }\end{array}$ & $\begin{array}{l}\text { Latent load } \\
\text { cooling tons } \\
\text { (2) }\end{array}$ & $\begin{array}{l}\text { Latent } \\
\text { load } \\
\text { COP }\end{array}$ & $\begin{array}{c}\text { Estimated sales price } \\
\text { Climate Changer modules } \\
\text { (3) }\end{array}$ & $\begin{array}{l}\text { Cost per ton } \\
\text { latent removal }\end{array}$ & $\begin{array}{l}\text { Comments } \\
\text { (4) }\end{array}$ \\
\hline 2,500 & 15.5 & NA & 8.5 & NA & $\$ 9,950$ & $\$ 1,171$ & $\begin{array}{l}\text { Requires an additional } 35,100 \text { BTUs of reheat energy to reach the } \\
\text { desired space neutral lower limit of } 70^{\circ} \mathrm{F}\end{array}$ \\
\hline 7,500 & 46.5 & NA & 25.5 & NA & $\$ 40,350$ & $\$ 1,190$ & $\begin{array}{l}\text { Requires an additional } 105,300 \text { BTUs of reheat energy to reach the } \\
\text { desired space neutral lower limit of } 70^{\circ} \mathrm{F}\end{array}$ \\
\hline 20,000 & 124 & NA & 68 & NA & $\$ 78,700$ & $\$ 1,157$ & $\begin{array}{l}\text { Requires an additional } 280,800 \text { BTUs of reheat energy to teach the } \\
\text { desired space neutral lower limit of } 70^{\circ} \mathrm{F}\end{array}$ \\
\hline
\end{tabular}

Notes: 1. Total tons based upon conditioning outdoor air from $84^{\circ} \mathrm{F}$ and 130 grains to $57^{\circ} \mathrm{F}$ and 70 grains.

2. Latent tons based upon reducing the humidity content of the outdoor air from 130 grains to 70 grains.

3. Estimated selling price of equipment based upon Climate Changer module pricing in 1996 dollars and required chiller tonnage at $\$ 500 /$ ton.

4. Based on the Phase 1 work, it is assumed that the preconditioned outdoor air needs to be provided dehumidified and at a space neutral temperature. This conventional overcooling-reheating approach requires the reheat energy shown in this column to reach the targeted $70-80^{\circ} \mathrm{F}$ delivery condition. 
Table 9. Desiccant-based cooling preconditioning approach

\begin{tabular}{|c|c|c|c|c|c|c|c|}
\hline \multicolumn{8}{|c|}{ Outdoor air condition: $94^{\circ} \mathrm{F}$ and 100 grains (typical dry bulb design condition) supplied at 53 grains and space neutral temperature } \\
\hline $\begin{array}{l}\text { Outdoor } \\
\text { air volume } \\
\text { (SCFM) }\end{array}$ & $\begin{array}{l}\text { Total cooling } \\
\text { tons } \\
\text { (1) }\end{array}$ & $\begin{array}{l}\text { Total } \\
\text { cooling } \\
\text { COP }\end{array}$ & $\begin{array}{l}\text { Latent load } \\
\text { cooling tons } \\
\text { (2) }\end{array}$ & $\begin{array}{l}\text { Latent } \\
\text { load } \\
\text { COP }\end{array}$ & $\begin{array}{c}\text { Estimated sales price } \\
\text { Climate Changer modules } \\
(3)\end{array}$ & $\begin{array}{l}\text { Cost per ton } \\
\text { latent removal }\end{array}$ & $\begin{array}{l}\text { Comments } \\
(4)\end{array}$ \\
\hline 2,500 & 8.5 & 0.9 & 6.7 & 0.71 & $\$ 14,700$ & $\$ 2,194$ & $\begin{array}{l}\text { Requires an additional } 18,900 \text { BTUs of post-cooling energy to reach } \\
\text { the desired space neutral lower limit of } 80^{\circ} \mathrm{F}\end{array}$ \\
\hline 7,500 & 25.5 & 0.9 & 20 & 0.71 & $\$ 30,200$ & $\$ 1,510$ & $\begin{array}{l}\text { Requires an additional } 56,700 \text { BTUs of post-cooling energy to reach } \\
\text { the desired space neutral lower limit of } 80^{\circ} \mathrm{F}\end{array}$ \\
\hline 20,000 & 68 & 0.9 & 53.6 & 0.71 & $\$ 64,800$ & $\$ 1,209$ & $\begin{array}{l}\text { Requires an additional } 151,200 \text { BTUs of post-cooling energy to reach } \\
\text { the desired space neutral lower limit of } 80^{\circ} \mathrm{F}\end{array}$ \\
\hline $\begin{array}{ll}\text { Notes: } & 1 . \\
& 2 . \\
& 3 . \\
& 4 .\end{array}$ & $\begin{array}{l}\text { Total tons base } \\
\text { Latent tons bas } \\
\text { Estimated selli } \\
\text { energy wheel } \mathrm{n} \\
\text { As per the Pha } \\
\text { approach requi }\end{array}$ & $\begin{array}{l}\text { d upon co } \\
\text { ng price o } \\
\text { nodules. } \\
\text { se } 1 \text { work, } \\
\text { res the po }\end{array}$ & $\begin{array}{l}\text { nditioning outd } \\
\text { educing the hur } \\
\text { f equipment bas } \\
\text { it is assumed t } \\
\text { st-cooling ener }\end{array}$ & $\begin{array}{l}\text { oor air } f \\
\text { nidity co } \\
\text { ed upon } \\
\text { at the pr } \\
\text { gy shown }\end{array}$ & $\begin{array}{l}\text { om } 94^{\circ} \mathrm{F} \text { and } 100 \text { grains to } 8 \\
\text { ttent of the outdoor air from } \\
\text { Climate Changer module pri } \\
\text { econditioned outdoor air nee } \\
\text { in this column to reach the }\end{array}$ & $\begin{array}{l}87^{\circ} \mathrm{F} \text { and } 53 \text { grai } \\
100 \text { grains to } 53 \\
\text { icing in } 1996 \text { dol } \\
\text { eds to be provide } \\
\text { targeted } 70-80^{\circ} 1\end{array}$ & $\begin{array}{l}\text { ins (see diagram DBC-1). } \\
\text { grains. } \\
\text { llars and estimates for the required SEMCO dehumidification and } \\
\text { ed dehumidified and at a space neutral temperature. This DBC } \\
\text { F delivery condition. }\end{array}$ \\
\hline \multicolumn{8}{|c|}{ Outdoor air condition: $84^{\circ} \mathrm{F}$ and 130 grains (typical dew point design condition) supplied at 70 grains and space neutral temperature } \\
\hline $\begin{array}{l}\text { Outdoor } \\
\text { air volume } \\
\text { (SCFM) }\end{array}$ & $\begin{array}{l}\text { Total cooling } \\
\text { tons } \\
(1)\end{array}$ & $\begin{array}{l}\text { Total } \\
\text { cooling } \\
\text { COP }\end{array}$ & $\begin{array}{l}\text { Latent load } \\
\text { cooling tons } \\
\text { (2) }\end{array}$ & $\begin{array}{l}\text { Latent } \\
\text { load } \\
\text { COP }\end{array}$ & $\begin{array}{c}\text { Estimated sales price } \\
\text { Climate Changer modules } \\
\text { (3) }\end{array}$ & $\begin{array}{l}\text { Cost per ton } \\
\text { latent removal }\end{array}$ & $\begin{array}{l}\text { Comments } \\
\text { (4) }\end{array}$ \\
\hline 2,500 & 7.1 & 0.64 & 8.5 & 0.76 & $\$ 14,700$ & $\$ 1,729$ & $\begin{array}{l}\text { Requires an additional } 31,590 \mathrm{BTU} \text { of post-cooling energy to reach } \\
\text { the desired space neutral lower limit of } 80^{\circ} \mathrm{F}\end{array}$ \\
\hline 7,500 & 21.3 & 0.64 & 25.5 & 0.76 & $\$ 30,200$ & $\$ 1,184$ & $\begin{array}{l}\text { Requires an additional } 94,770 \text { BTUs of post-cooling energy to reach } \\
\text { the desired space neutral lower limit of } 80^{\circ} \mathrm{F}\end{array}$ \\
\hline 20,000 & 56.8 & 0.64 & 68 & 0.76 & $\$ 64,800$ & $\$ 953$ & $\begin{array}{l}\text { Requires an additional } 252,720 \text { BTUs of post-cooling energy to reach } \\
\text { the desired space neutral lower limit of } 80^{\circ} \mathrm{F}\end{array}$ \\
\hline
\end{tabular}

Notes: 1. Total tons based upon conditioning outdoor air from $84^{\circ} \mathrm{F}$ and 130 grains to $91.7^{\circ} \mathrm{F}$ and 70 grains (see diagram DBC-2).

2. Latent tons based upon reducing the humidity content of the outdoor air from 130 grains to 70 grains.

3. Estimated selling price of equipment based upon Climate Changer module pricing in 1996 dollars and estimates for the required SEMCO dehumidification and energy wheel modules.

4. As per the Phasc 1 work, it is assumed that the preconditioned outdoor air needs to be provided dehumidified and at a space neutral temperature. This DBC approach requires the post-cooling energy shown in this column to reach the targeted $70-80^{\circ} \mathrm{F}$ delivery condition. 
Table 10. Dehumidification-total energy recovery hybrid

\begin{tabular}{|c|c|c|c|c|c|c|c|}
\hline \multicolumn{8}{|c|}{ Outdoor air condition: $94^{\circ} \mathrm{F}$ and 100 grains (typical dry bulb design condition) supplied at 45 grains and space neutral temperature } \\
\hline $\begin{array}{l}\text { Outdoor } \\
\text { air volume } \\
(\mathrm{SCFM})\end{array}$ & $\begin{array}{l}\text { Total cooling } \\
\text { tons } \\
(1)\end{array}$ & $\begin{array}{l}\text { Total } \\
\text { cooling } \\
\text { COP }\end{array}$ & $\begin{array}{l}\text { Latent load } \\
\text { cooling tons } \\
\text { (2) }\end{array}$ & $\begin{array}{l}\text { Latent } \\
\text { load } \\
\text { COP }\end{array}$ & $\begin{array}{c}\text { Estimated sales price } \\
\text { Climate Changer modules } \\
\text { (3) }\end{array}$ & $\begin{array}{l}\text { Cost per ton } \\
\text { latent removal }\end{array}$ & $\begin{array}{l}\text { Comments } \\
(4)\end{array}$ \\
\hline 2,500 & 6.8 & 0.98 & 7.8 & 1.1 & $\$ 15,750$ & $\$ 2,019$ & $\begin{array}{l}\text { Requires an additional } 59,400 \text { BTUs of post-cooling energy to reach } \\
\text { the desired space neutral upper limit of } 80^{\circ} \mathrm{F}\end{array}$ \\
\hline 7,500 & 20.4 & 0.98 & 23.4 & 1.1 & $\$ 31,350$ & $\$ 1,340$ & $\begin{array}{l}\text { Requires an additional } 178,200 \text { BTUs of post-cooling energy to reach } \\
\text { the desired space neutral upper limit of } 80^{\circ} \mathrm{F}\end{array}$ \\
\hline 20,000 & 51.1 & 0.98 & 62.1 & 1.1 & $\$ 67,850$ & $\$ 1,087$ & $\begin{array}{l}\text { Requires an additional } 475,200 \mathrm{BTU} \text { s of post-cooling cncrgy to rcach } \\
\text { the desired space neutral upper limit of } 80^{\circ} \mathrm{F}\end{array}$ \\
\hline \multicolumn{8}{|c|}{$\begin{array}{l}\text { Notes: 1. Total tons based upon conditioning outdoor air from } 94^{\circ} \mathrm{F} \text { and } 100 \text { grains to } 87^{\circ} \mathrm{F} \text { and } 53 \text { grains (see diagram DH/ER Hybrid-1). } \\
\text { 2. Latent tons based upon reducing the humidity content of the outdoor air from } 100 \text { grains to } 53 \text { grains. } \\
\text { 3. Estimated selling price of equipment based upon Climate Changer module pricing in } 1996 \text { dollars and estimates for the required SEMCO dehumidification and } \\
\text { energy wheel modules. } \\
\text { 4. As per the Phase } 1 \text { work, it is assumed that the preconditioned outdoor air needs to be provided dehumidified and at a space neutral temperature. This DH/ER hybrid } \\
\text { approach requires the post-cooling energy shown in this column to reach the targeted } 70-80^{\circ} \mathrm{F} \text { delivery condition. }\end{array}$} \\
\hline \multicolumn{8}{|c|}{ Outdoor air condition: $84{ }^{\circ} \mathrm{F}$ and 130 grains (typical dew point design condition) supplied at 45 grains and space neutral temperature } \\
\hline $\begin{array}{l}\text { Outdoor } \\
\text { air volume } \\
(\mathrm{SCFM})\end{array}$ & $\begin{array}{l}\text { Total cooling } \\
\text { tons } \\
\text { (1) }\end{array}$ & $\begin{array}{l}\text { Total } \\
\text { cooling } \\
\text { COP }\end{array}$ & $\begin{array}{l}\text { Latent load } \\
\text { cooling tons } \\
\text { (2) }\end{array}$ & $\begin{array}{l}\text { Latent } \\
\text { load } \\
\text { COP }\end{array}$ & $\begin{array}{l}\text { Estimated sales price } \\
\text { Climate Changer modules } \\
\text { (3) }\end{array}$ & $\begin{array}{l}\text { Cost per ton } \\
\text { latent removal }\end{array}$ & $\begin{array}{l}\text { Comments } \\
\text { (4) }\end{array}$ \\
\hline 2,500 & 7.3 & 0.72 & 12 & 1.2 & $\$ 15,750$ & $\$ 1,313$ & $\begin{array}{l}\text { Requires an additional } 75,600 \text { BTUs of post-cooling energy to reach } \\
\text { the desired space neutral upper limit of } 80^{\circ} \mathrm{F}\end{array}$ \\
\hline 7,500 & 21.9 & 0.72 & 36 & 1.2 & $\$ 31,350$ & $\$ 871$ & $\begin{array}{l}\text { Requires an additional } 226,800 \text { BTUs of post-cooling energy to reach } \\
\text { the desired space neutral upper limit of } 80^{\circ} \mathrm{F}\end{array}$ \\
\hline 20,000 & 58.4 & 0.72 & 96.3 & 1.2 & $\$ 67,850$ & $\$ 705$ & $\begin{array}{l}\text { Requires an additional } 604,800 \text { BTUs of post-cooling energy to reach } \\
\text { the desired space neutral upper limit of } 80^{\circ} \mathrm{F}\end{array}$ \\
\hline
\end{tabular}

Notes: 1. Total tons based upon conditioning outdoor air from $94^{\circ} \mathrm{F}$ and 100 grains to $87^{\circ} \mathrm{F}$ and 53 grains (see diagram DH/ER Hybrid-2).

2. Latent tons hased upon reducing the humidity content of the outdoor air from 130 grains to 70 grains.

3. Estimated selling price of equipment based upon Climate Changer module pricing in 1996 dollars and estimates for the required SEMCO dehumidification and energy wheel modules.

4. As per the Phase 1 work, it is assumed that the preconditioned outdoor air needs to be provided dehumidified and at a space neutral temperature. This DH/ER hybrid approach requires the post-cooling energy shown in this column to reach the targeted $70-80^{\circ} \mathrm{F}$ delivery condition. 
When the dehumidification-total energy recovery hybrid (Table 10) is compared in a similar fashion, the advantage of this approach over conventional cooling is very clear. First, it allows for much drier air than is possible with conventional cooling approaches. Second, the cost per latent ton removed is less. And finally, the cost of operation is much lower, and the system provides for time total energy recovery in winter. It appears a clear winner.

\subsection{COMPARING SYSTEMS BASED ON COST PER TON OF LATENT AIR CONDITIONING}

Tables 11 and 12 show the difference in estimated cost per ton for the three approaches discussed at different design conditions and for both total and latent output. Table 11 compares the conventional overcooling and reheating approach with a DBC active desiccant system. Table 12 compares the conventional cooling approach with the dehumidification-total energy recovery hybrid approach.

Table 11 shows that the cost advantage associated with total cooling tons provided disappears for the conventional cooling approach when the systems are compared based on latent cooling output. Table 12 shows how the dehumidification-total energy recovery hybrid results in a significant cost advantage over the conventional cooling system when they are compared based on latent capacity.

Table 11. Comparison of the estimated first cost based on both total and latent cooling tonnage provided: conventional overcooling vs DBC approach

(based on a $7500 \mathrm{cfm}$ outdoor air preconditioning system)

\begin{tabular}{lccccc}
\hline \multirow{2}{*}{$\begin{array}{c}\text { Design conditions outdoor air } \\
\text { (grains delivered from system) }\end{array}$} & \multicolumn{2}{c}{$\begin{array}{c}\text { Estimated first cost selling price/ } \\
\text { total cooling tons provided }\end{array}$} & & \multicolumn{2}{c}{$\begin{array}{c}\text { Estimated first cost selling price/ } \\
\text { latent cooling tons provided }\end{array}$} \\
\cline { 2 - 3 } & Overcooling & DBC approach & & Overcooling & DBC approach \\
\hline $\begin{array}{l}94^{\circ} \mathrm{F} \text { and } 100 \text { grains } \\
\text { (typical dry bulk BIN design condition) }\end{array}$ & $\$ 644$ & $\$ 1884$ & & $\$ 1577$ & $\$ 1510$ \\
$\begin{array}{l}84^{\circ} \mathrm{F} \text { and 130 grains } \\
\text { (typical dew point design condition) }\end{array}$ & $\$ 652$ & $\$ 1417$ & & $\$ 1190$ & $\$ 1184$ \\
\hline
\end{tabular}

Notes: 1. Conventional cooling approach assumes the cost of chiller and cooling tower at $\$ 500 /$ ton.

2. System costs estimates from Table 2 from Phase 1 work.

3. Based on supplying outdoor air dehumidified to 53 grains and 70 grains, respectively, as in Figs. A.6 and A.7.

Table 12. Comparison of the estimated first cost based on both total and latent cooling tonnage provided: conventional overcooling vs dehumidification-total energy recovery hybrid (based on a $7500 \mathrm{cfm}$ outdoor air preconditioning system)

\begin{tabular}{lccccc}
\hline \multirow{2}{*}{$\begin{array}{c}\text { Design conditions outdoor air } \\
\text { (grains delivered from system) }\end{array}$} & \multicolumn{2}{c}{$\begin{array}{c}\text { Estimated first cost selling pricel } \\
\text { total cooling tons provided }\end{array}$} & & \multicolumn{2}{c}{$\begin{array}{c}\text { Estimated first cost selling price/ } \\
\text { latent cooling tons provided }\end{array}$} \\
\cline { 2 - 3 } \cline { 5 - 6 } & Overcooling & DH/ER hybrid & & Overcooling & DH/ER hybrid \\
\hline $\begin{array}{l}94^{\circ} \mathrm{F} \text { and } 100 \text { grains } \\
\text { (typical dry bulk BIN design condition) }\end{array}$ & $\$ 559$ & $\$ 1119$ & & $\$ 1518$ & $\$ 1291$ \\
$\begin{array}{l}84^{\circ} \mathrm{F} \text { and 130 grains } \\
\text { (typical dew point design condition) }\end{array}$ & $\$ 625$ & $\$ 1379$ & & $\$ 987$ & $\$ 839$ \\
\hline
\end{tabular}

Notes: 1. Conventional cooling approach assumes the cost of chiller and cooling tower at $\$ 500 /$ ton.

2. System costs estimates from Table 2 from Phase 1 work.

3. Based on supplying outdoor air dehumidified to 45 grains as in Figs. A.7 and A.8. 


\subsection{COMPARING SYSTEM OPERATING EFFICIENCY BASED ON LATENT COOLING CAPACITY}

It is clearly difficult (if not inappropriate) to attempt to compare the operating efficiency (i.e., COP) of a conventional cooling approach with that of an active desiccant system. There are many factors to consider, and the $\mathrm{kW} /$ ton efficiency of conventional cooling equipment varies widely based on operating conditions and equipment selected. Nevertheless, a quick, simplified comparison of the systems discussed based on latent capacity produces an interesting end result.

Figure A.2 summarizes the latent COP (latent BTU out/BTU input) for the conventional cooling, DBC and dehumidification-total energy recovery hybrid systems. This analysis is based upon the dew point design condition of $84^{\circ} \mathrm{F}$ and 130 grains; it assumes an electrical power plant and transmission efficiency of $45 \%$ and assumes direct gas-fired regencration of the active desiccant systems.

The results shown are surprising in that the calculated latent COP value for the DBC approach is $70 \%$ of that calculated for the conventional overcooling approach, and the COP value calculated for the dehumidification-total energy recovery hybrid is actually higher than that of the conventional cooling approach.

\subsection{KEY CONCLUSIONS BASED ON PHASE 2 WORK}

The more thorough analysis conducted in Phase 2 indicates that the markets initially targeted by the Phase 1 market evaluation-including hospitals, nursing homes/assisted living centers, research facilities, hotels/dormitories, retail stores and school facilities-continue to provide a significant opportunity for a costcompetitive active desiccant-based outdoor air preconditioning system. The estimated annual sales potential for these market segments alone is in excess of $\$ 82$ million.

All of this potential could be satisfied by a product offering consisting of three system configurations (Figs. 1-6) produced from current Trane Climate Changer modules combined with SEMCO active and passive desiccant wheel cassettes. If a cost-effective active desiccant module could be successfully developed to couple with the Trane Voyager packaged rooftop cooling units, approximately $30 \%$ of this identified potential market - plus an additional $\$ 15$ million attributable to the restaurant market segment-could likely be served with this equipment.

The engineering community is beginning to understand the benefits provided by decoupling outdoor air latent loads from conventional HVAC equipment in their designs. Trane and other major HVAC manufacturers are beginning to market dual-path overcooling with compressorized reheating and various total energy recovery preconditioning systems. Their interest simplifies the task of gaining market acceptance for active desiccant approaches. Other trends-including revised dew point weather data, utility deregulation, growing awarcness of humidity control, and the rise in childhood asthma -are all strong market drivers favoring active desiccant solutions.

The needs of the targeted markets can be effectively met by three system configurations: the DBC, dehumidification-total energy recovery hybrid, and dehumidification-only approaches. Since the dehumidification-total energy recovery hybrid configuration is a combination of the current total energy recovery preconditioner and the dehumidification-only system, only two new configurations are actually required. It is thought that minimizing the number of available options will limit confusion and the potential for misapplication and will simplify sales support, allowing the sales engineers to remain focused on the benefits of this new technology. 
The feedback from the market continues to support a compact product optimized to provide the most latent cooling capacity (pounds of moisture removal) for a given system first cost. Most projects will involve systems of under $10,000 \mathrm{cfm}$, a size where the active desiccant system is least competitive with conventional alternatives, further emphasizing the need for a cost-driven design minimizing the $\$ /$ ton latent cooling ratio. A significant portion of the targeted market would be best served by a product that can be regenerated at temperatures between 200 and $250^{\circ} \mathrm{F}$ (maximum). Based on these and other conclusions reached based on market feedback, the following key design objective was determined:

Design the most compact active desiccant system(s) possible, maximizing the latent cooling (grain reduction) vs. cost ratio, utilizing a dehumidification wheel capable of removing approximately 60 grains of moisture from outdoor air having a relative humidity of $80-90 \%$ (dew point design data) and using a regeneration temperature in the range of 180 to $225^{\circ} \mathrm{F}$.

The 60-grain removal goal is based upon the new ASHRAE dew point design data of $84^{\circ} \mathrm{F}$ and 130 grains. A 60 -grain reduction would deliver air at 70 grains, or a $57^{\circ} \mathrm{F}$ dew point, which is on par with the humidity level typically delivered by packaged equipment and low enough to maintain most spaces at $60 \% \mathrm{RH}$. At more moderate outdoor air humidity levels, or with the dehumidification-total energy recovery hybrid approach, much lower grain levels can be delivered.

It was concluded that in order to provide for the most cost-effective active desiccant solution, traditionally high wheel face velocities would be required through the process side of the dehumidification wheel. At 600 $\mathrm{ft} / \mathrm{min}$, the supply airflow through the dehumidification wheel would exceed $80 \%$ of the rated capacity of the Climate Changer modules, resulting in a cost-effective system solution, one of the key design criteria.

Testing of the SEMCO 1M wheel module suggests that the 60 -grain reduction performance goal at the 600 to $650 \mathrm{ft} / \mathrm{min}$ process face velocity should be achievable with the incorporation of a purge section and other modifications to the wheel cassette and seals. Modeling has predicted very respectable COPs for the most promising active desiccant system approaches even at the high face velocities (see Figs. A.5-A.8). When actual dehumidification wheel test data are used to revise the operating cost estimates completed as part of the Phase 1 work, the active systems look more attractive than previously thought because of an approximate $5 \%$ reduction in energy consumption required by the active systems (see Figs. A.1-A.4).

It was determined that the increased latent load associated with the new ASHRAE weather data had both a positive and negative effect on active desiccant systems. On the plus side, the greater humidity levels and higher inlet relative humidities result in an increased latent capacity for a given system. On the down side, the greater the grain reduction required, the greater the regeneration energy required and the greater the heat of adsorption. The result is a much higher temperature leaving the dehumidification wheel than would be associated with the dry bulb design condition (Fig. A.5 vs Fig. A.6).

At the same time that the dew point design condition produces a much higher temperature after the dehumidification wheel, it unfortunately also provides less post-cooling capacity because the outdoor air condition is near saturation, rendering the indirect evaporative cooling side of the system ineffective (see Fig. A.6). As a result, post-cooling after an active desiccant system is unavoidable. It is therefore concluded that trading a slight increase in post-cooling requirement for a significant reduction in first cost of the overall system (by using a small dehumidification wheel, for example) is appropriate. 
Finally, given the intended use of this product, to provide latent air conditioning, it appears to be inappropriate to compare it with other, more conventional approaches based on total cooling capacity. It should be rated based on tons of latent cooling capacity provided. Likewise, the COP should be based on the latent cooling output/energy input.

Tables 8-13 show that when the conventional overcooling approach is compared with the most promising active desiccant system, based on latent cooling capacity provided, the active desiccant systems are cost competitive and provide an opportunity for significant energy savings along with the advantage of delivering drier air (dew points lower than obtainable with conventional cooling systems).

The conclusion regarding the cost competitiveness of the active systems is contingent upon using relatively high wheel face velocities, matching the supply and regeneration wheel areas with the flow configuration of a traditional air handling system (i.e., a 60/40 split), and using mass-produced, pre-engineered air handling modules such as the current Trane Climate Changer offering.

The projected selling prices for the most promising active desiccant systems described by this report and built from Climate Changer modules are approximately $40 \%$ lower than those of active desiccant systems currently on the market. The projected selling prices are also $30 \%$ lower than those of compressorized packaged overcooling/reheating units currently marketed by some Trane offices (based on a 5000-cfm system).

Given the trend in the HVAC market toward improved humidity control, the sizable sales opportunities identified for active desiccant systems, and the significant reduction in cost (over equipment currently marketed) made possible by the use of a mass-produced Climate Changer type product, it appears likely that one or more of the major HVAC equipment manufacturers will choose to offer active desiccant systems in the near future.

Table 13. Comparison of system latent cooling COP based on dew point design data (based on outdoor air conditions of $84^{\circ} \mathrm{F}$ and 130 grains)

\begin{tabular}{cccc}
\hline $\begin{array}{c}\text { Supply air humidity content } \\
\text { (grains delivered from system) }\end{array}$ & $\begin{array}{c}\text { Conventional overcooling } \\
\text { with reheat } \\
\text { (COP) }\end{array}$ & $\begin{array}{c}\text { DBC approach } \\
\text { (COP) }\end{array}$ & $\begin{array}{c}\text { Dehumidification-total } \\
\text { energy recovery hybrid } \\
\text { (COP) }\end{array}$ \\
\hline 70 grains & 1.1 & 0.76 & - \\
45 grains & 1 & - & 1.2 \\
\hline
\end{tabular}

Notes: 1. Assumes $0.6 \mathrm{~kW} /$ ton for conventional cooling to 70 grains, $1 \mathrm{~kW} /$ ton for 45 grain delivery.

2. Assumes power generation and transmission efficiency of $35 \%$ from electrical power plant.

3. COP calculated by dividing the latent cooling output by the energy input to run chiller or regenerale the desiccant wheel.

4. Fan heat, pressure loss through the systems, pump or cooling tower energy are not considered in this analysis. 


\section{REFERENCES}

Arundel, A. V., E. M. Sterling, J. H. Biggin, and T. D. Sterling 1986. "Indirect health effects of relative humidity in indoor environments," Env. Health Perspectives, 65 351-61, March.

ASHRAE (American Society of Heating, Refrigerating and Air-conditioning Engineers) 1997. Handbook of Fundamentals, Atlanta.

Bascom, R. 1997. "Plenary paper: Health and indoor air quality in schools-a spur to action or false alarm?" 1:3-13 in Proceedings of Healthy Buildings/IAQ '97, American Society of Heating, Refrigerating and Airconditioning Engineers, Bethesda, Md.

Collier, R. K. 1988. Advanced Desiccant Materials Assessment: Phase II, GRI-88/0125, Gas Research Institute, Chicago, January.

Hodgson, M. J. 1997. Proceedings of Healthy Buildings/IAQ '97, American Society of Heating, Refrigerating and Air-conditioning Engineers, Bethesda, Md. 
APPENDIX A 


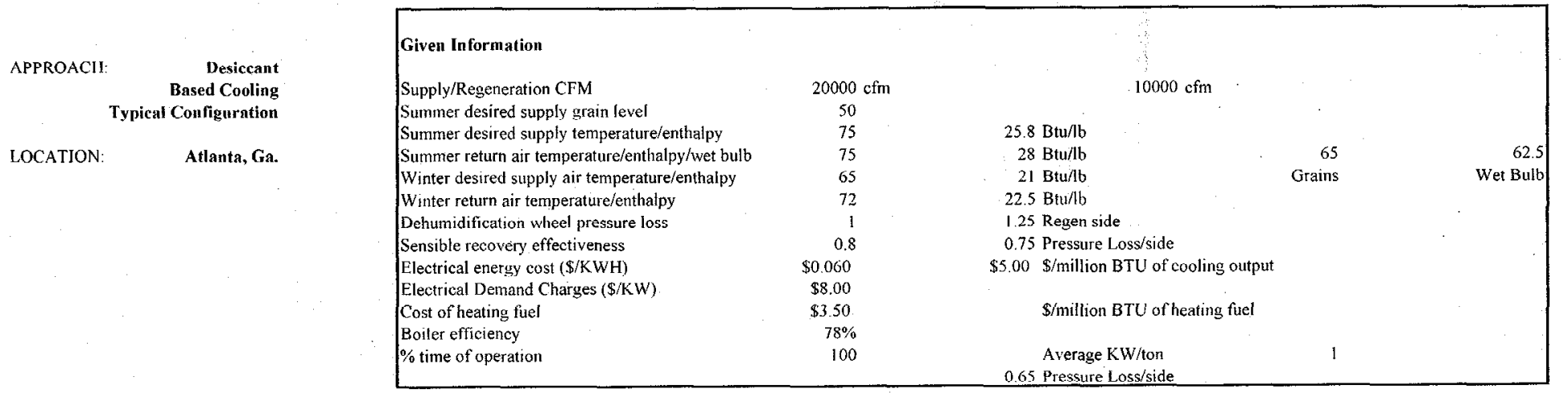

Desiccant Based Cooling Approach

\section{WEATHER DATA (TWELVE YEAR AVERAGE)}

$\begin{array}{ccccc}\text { OUTDOOR } & \text { OUTDOOR } & \text { ANNUAL } & \text { ENTHALPY } & \text { MOISTURE } \\ \text { DRY BULB } & \text { WET BULB BIN HOIRS } & \text { RTU// B } & \text { GR /I.B }\end{array}$

\begin{tabular}{|c|c|c|c|}
\hline 102 & 73 & 1 & 35.9 \\
\hline 97 & 74 & 20 & 36.8 \\
\hline 92 & 74 & 135 & 36.9 \\
\hline 87 & 72 & 367 & 35.2 \\
\hline 82 & 70 & 612 & 33.5 \\
\hline 77 & 69 & 839 & 32.7 \\
\hline 72 & 67 & 1201 & 31.2 \\
\hline 67 & 60 & 986 & 26.2 \\
\hline 62 & 57 & 845 & 24.3 \\
\hline 57 & 52 & 773 & 21.3 \\
\hline 52 & 48 & 709 & 19.2 \\
\hline 47 & 43 & 665 & 16.7 \\
\hline 42 & 39 & 608 & 14.8 \\
\hline 37 & 34 & 471 & 12.7 \\
\hline 32 & 30 & 303 & 11.1 \\
\hline 27 & 25 & 134 & 9.2 \\
\hline 22 & 21 & 51 & .7 .7 \\
\hline 17 & 16 & 23 & 6.0 \\
\hline 12 & 11 & 9 & 4.4 \\
\hline 7 & 6 & 1 & 29 \\
\hline .2 & 2 & $i$ & 1.7 \\
\hline-3 & -3 & 0 & 0.2 \\
\hline
\end{tabular}

72.2
85.9
94.0
90.9
88.3
91.2
89.2
65.0
60.6
49.4
43.2
34.9
30.8
24.6
22.0
17.5
16.0
12.7
10.1
7.8
7.9
6.3

(A)
BTU Required
to dehumidify
with dehumidificaiton wheel
818994
17646139
118512628
306375129
542299688
762351575
974532660
912927148
751744120

Subtotal Energy Cost

762351575

29532660

744120
(B)

BTU Required
to Post Cool

(cooling mode)

Fan Horsepower cos
for the systcm assuming Heat \& Humidify 1.5 " of ESP and cooling (heating mode) pump and tower (note I)

\section{$818994 \quad 29253$}

17646139
18512628

\begin{tabular}{l}
7833685 \\
\hline
\end{tabular}

Cooling Season Energy Cost

Heating Season Energy Cost

\$ $\$ 27,274$ Total Annual Energy Cost Demand Charges (Cooling Season Only)

$\$ 1,599$ Cooling Approach $\$ 35,463$

Fig. A.1. Annual operating cost estimate for the traditional desiccant-based cooling approach. 


\begin{tabular}{|c|c|c|c|c|c|c|c|c|c|}
\hline (E) & (F) & (G) & $(\mathrm{H})$ & (I) & (I) & (K) & (I.) & (M) & $(\mathrm{N})$ \\
\hline Humidity Grains & Temperature & $\begin{array}{r}\text { Enthalpy } \\
\text { Entering DH }\end{array}$ & Temperature Leaving & $\begin{array}{l}\text { Humidity Leaving } \\
\text { the Dehumidification }\end{array}$ & $\begin{array}{l}\text { Regeneration } \\
\text { Temperature }\end{array}$ & $\begin{array}{l}\text { Temperature Leaving } \\
\text { Rcgen Evaporative }\end{array}$ & $\begin{array}{l}\text { Temperature } \\
\text { to Regeneration }\end{array}$ & $\begin{array}{l}\text { Temperature Leaving } \\
\text { Sensible Wheel }\end{array}$ & $\begin{array}{r}\text { Enthalpy } \\
\text { Eeaving Sensible }\end{array}$ \\
\hline $\begin{array}{r}\text { Entering DH } \\
\text { Wheel }\end{array}$ & $\begin{array}{r}\text { Entering DH } \\
\text { Wheel }\end{array}$ & $\begin{array}{r}\text { Entering DH } \\
\text { Wheel }\end{array}$ & $\begin{array}{r}\text { the Dehumidification } \\
\text { Wheel }\end{array}$ & $\begin{array}{r}\text { the Dehumidification } \\
\text { Wheel }\end{array}$ & $\begin{array}{r}\text { Temperature } \\
\text { Required }\end{array}$ & $\begin{array}{r}\text { Regen Evaporative } \\
\text { Cooler }\end{array}$ & $\begin{array}{r}\text { to Regeneration } \\
\text { Coil }\end{array}$ & $\begin{array}{l}\text { Sensible Wheel } \\
\text { To Cooling Coil }\end{array}$ & $\begin{array}{r}\text { Leaving Sensible } \\
\text { Wheel }\end{array}$ \\
\hline 72.2 & 102.0 & 35.9 & 126.8 & 50 & 190 & 63.8 & 114.2 & 76 & \\
\hline 85.9 & 97.0 & 36.8 & 131.9 & 50 & 200 & 63.8 & {$[18.3$} & 77 & \\
\hline 94.0 & 92.0 & 36.9 & 132.5 & 50 & 200 & 63.8 & 118.7 & 77 & \\
\hline 90.9 & 87.0 & 35.2 & 124.9 & 50 & 190 & 63.8 & 112.7 & 76 & \\
\hline 88.3 & 82.0 & 33.5 & 119.0 & 50 & 190 & 63.8 & 108.0 & 75 & \\
\hline 91.2 & 77.0 & 32.7 & 116.4 & 50 & 190 & 63.8 & 105.9 & 74 & \\
\hline 89.2 & 72.0 & 31.2 & 108.9 & 50 & 175 & 63.8 & 99.9 & 73 & \\
\hline 65.0 & 67.0 & 26.2 & 89.4 & 50 & 170 & 63.8 & 84.3 & 69 & \\
\hline 60.6 & 62.0 & 24.3 & 81.1 & 50 & 160 & 63.8 & 77.6 & 67 & \\
\hline 30.8 & 42.0 & 14.8 & & & & & & 66 & 20.6 \\
\hline 24.6 & 37.0 & 12.7 & & & & & & 65 & 19.4 \\
\hline 22.0 & 32.0 & 11.1 & & & & & & 64 & 18.8 \\
\hline 17.5 & 27.0 & 9.2 & & & & & & 63 & 17.8 \\
\hline 16.0 & 22.0 & 7.7 & & & & & & 62 & 17,4 \\
\hline 12.7 & 17.0 & 6.0 & & & & & & 61 & 16.6 \\
\hline 10.1 & 12.0 & 4.4 & & & & & & 60 & 16.0 \\
\hline 7.8 & 7.0 & 2.9 & & & & & & 59 & 15.4 \\
\hline 7.9 & 2.0 & 1.7 & & & & & & 58 & 15.1 \\
\hline
\end{tabular}

Note 1: Assumes parasitic loss for all components in the system as well as an average $0.3 \mathrm{KW} /$ ton for operating the chilled water pumps and the cooling tower.

Fig. A.1 (continued) 


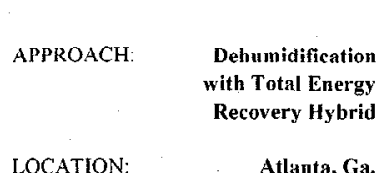

Atlanta, Ga.

LOCATION

\begin{tabular}{|c|c|c|c|c|}
\hline \multicolumn{5}{|l|}{ Given Information } \\
\hline Supply/Regeneration CFM & $20000 \mathrm{cfm}$ & & $7000 \mathrm{cfm}$ & \\
\hline Summer desired supply grain level & 50 & & & \\
\hline Summer desired supply temperature/enthalpy & 75 & 25.8 & Btu/b & \\
\hline Summer return air temperature/enthalpy/grains & 75 & & Btu/b & 65 Grains \\
\hline Winter desired supply air temperatureienthalpy & 65 & & Btu/lb & \\
\hline Winter return air temperature/enthalpy/grains & 72 & 22.5 & Btu/lb & 34 Grains \\
\hline Dehumidification wheel pressure loss & 1 & 1.25 & Regen side & \\
\hline Total recovery effectiveness & 0.76 & 0.75 & Pressure Loss/side & \\
\hline Electrical energy cost $(\$ / K W H)$ & $\$ 0.060$ & $\$ 5.00$ & \$/million BTU of cooling output & \\
\hline Electrical Demand Charges $(\$ / \mathrm{KW})$ & $\$ 8.00$ & & & \\
\hline Cost of heating fuel/Summer cooling rate & $\$ 3.50$ & & $\$ /$ million BTU of heating fuel & \\
\hline Boiler efficiency & $78 \%$ & & & \\
\hline$\%$ time of operation & 100 & & Average $\mathrm{KW} /$ ton & 1 \\
\hline
\end{tabular}

Desiccant Dehumidification/Total Recovery/Hybrid

\section{WEATHER DATA (TWELVE YEAR AVERAGE)}

\begin{tabular}{|c|c|c|c|}
\hline $\begin{array}{l}\text { OUTD } \\
\text { DRY }\end{array}$ & $\begin{array}{l}\text { OUTDOOR } \\
\text { WFT RUIER B }\end{array}$ & $\begin{array}{l}\text { ANNUAL } \\
\text { BIN HOURS }\end{array}$ & $\begin{array}{c}\text { ENTHALPY } \\
\text { BTU/LB }\end{array}$ \\
\hline
\end{tabular}

(A)
BTU Require to dehumidify
with dehumidificaiton wheel BTU Required to for the system assuming

$$
\begin{aligned}
& 72.2 \\
& 85.9 \\
& 94.0 \\
& 90.9 \\
& 88.3 \\
& 91.2 \\
& 89.2 \\
& 65.0 \\
& 60.6 \\
& 49.4 \\
& 43.2 \\
& 34.9 \\
& 30.8 \\
& 24.6 \\
& 22.0 \\
& 17.5 \\
& 16.0 \\
& 12.7 \\
& 10.1 \\
& 7.8 \\
& 7.9 \\
& 6.3
\end{aligned}
$$

Subtotal Fnergy Cost

\section{(B)} BTU Required
to Post $\mathrm{CoO}$ (cooling mode) (C) Heat \& Humidify
(heating mode)

Fan Horsepower cost $1.5^{\prime \prime}$ of ESP and cooling

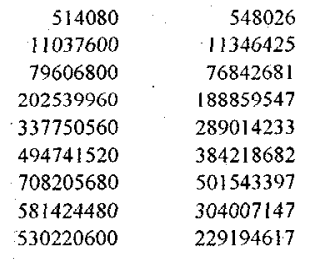

$\begin{array}{rr} & \$ 1 \\ & \$ 24 \\ & \$ 164 \\ & \$ 447 \\ & \$ 746 \\ & \$ 1,022 \\ & \$ 1,463 \\ & \$ 1,201 \\ & \$ 1,030 \\ & \$ 942 \\ & \$ 864 \\ & \$ 810 \\ 19354883 & \$ 741 \\ 43262080 & \$ 574 \\ 41425492 & \$ 369 \\ 25399911 & \$ 163 \\ 11703398 & \$ 62 \\ 636959 & \$ 28 \\ 2897763 & \$ 11 \\ 365009 & \$ 1 \\ 398275 & \$ 1\end{array}$

$\$ 13,710$

$\$ 9,928$

$\$ 529$

$\$ 10,666$
Cooling Season Energy Cost Demand Charges (Cooling Season Ouly)
\$29,246 Total Annual Energy Cost Estimate $\$ 5,096$ for Desiccant Delumidification/

Fig. A.2. Annual operating cost estimate for the dehumidification/total energy recovery hybrid approach. 
(E)

Humidity Grains Entering DH Wheel

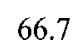

70.0

72.0

71.2

70.6

71.3
70.8

65.0

63.9

33.2
31.7

31.1

30.0

29.7

28.9

28.3

27.7

27.7
(F)

Temperature

Entering DH

Wheel

81.5

80.3

79.1
77.9

76.7

75.5

74.3

73.1

71.9

(G)

Enthalpy

Entering DH

Wheel

30.0

30.2

30.2

29.8

29.4

29.3

28.9

27.7

27.2

(H)

Temperature Leaving

the Dehumidification

Wheel

100.4

101.3

101.4

98.8

96.9

96.2

94.3

89.3

87.6
(I)

Humidity Lcaving

the Dehumidification Wheel

50
50

50

50
50

50

50
50
50

50
50
(J)

Regeneration

Temperature

Required

170

170

170

160

155

155

150

145

145

Note 1: Assumes parasitic loss for all components in the system as well as an average $0.3 \mathrm{KW} / \mathrm{ton}$

for operating the chilled water pumps and the cooling tower.

Fig. A.2 (continued) 


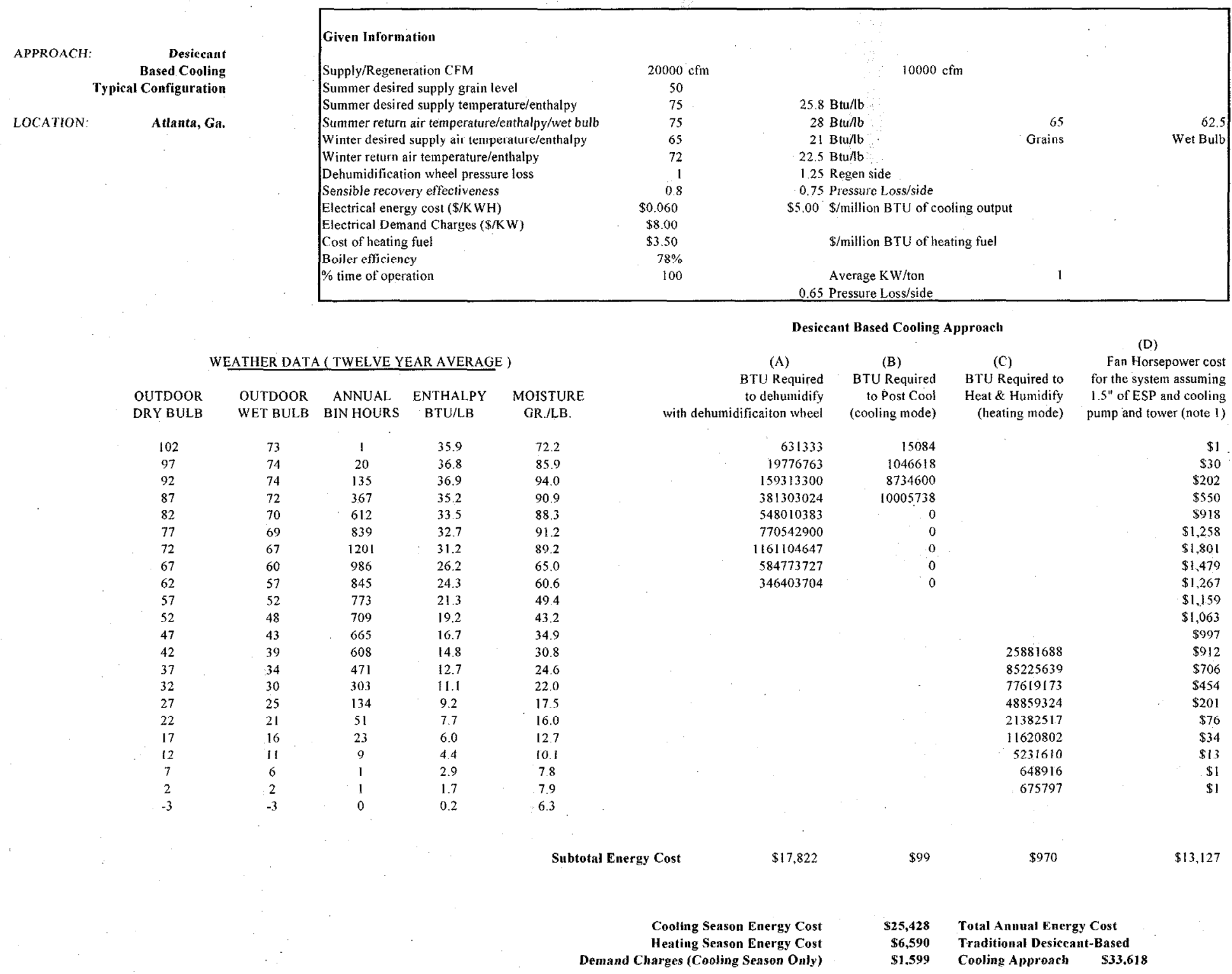

Fig. A.3. Annual operating cost estimate for the traditional desiccant-based cooling approach, modified to reflect the performance of the SEMCO $1 \mathrm{M}$ wheel. 


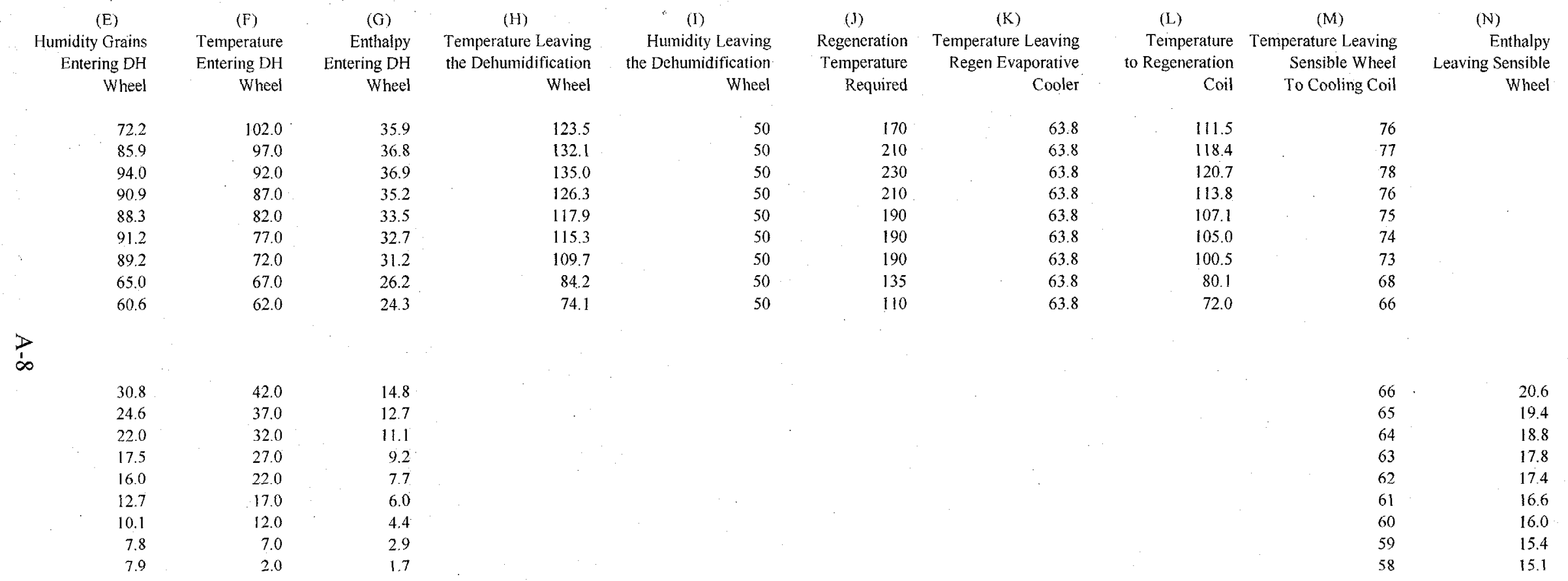

Note 1: Assumes parasitic loss for all components in the system as well as an average $0.3 \mathrm{KW} / \mathrm{ton}$ for operating the chilled water pumps and the cooling tower.

Fig. A.3 (continued) 


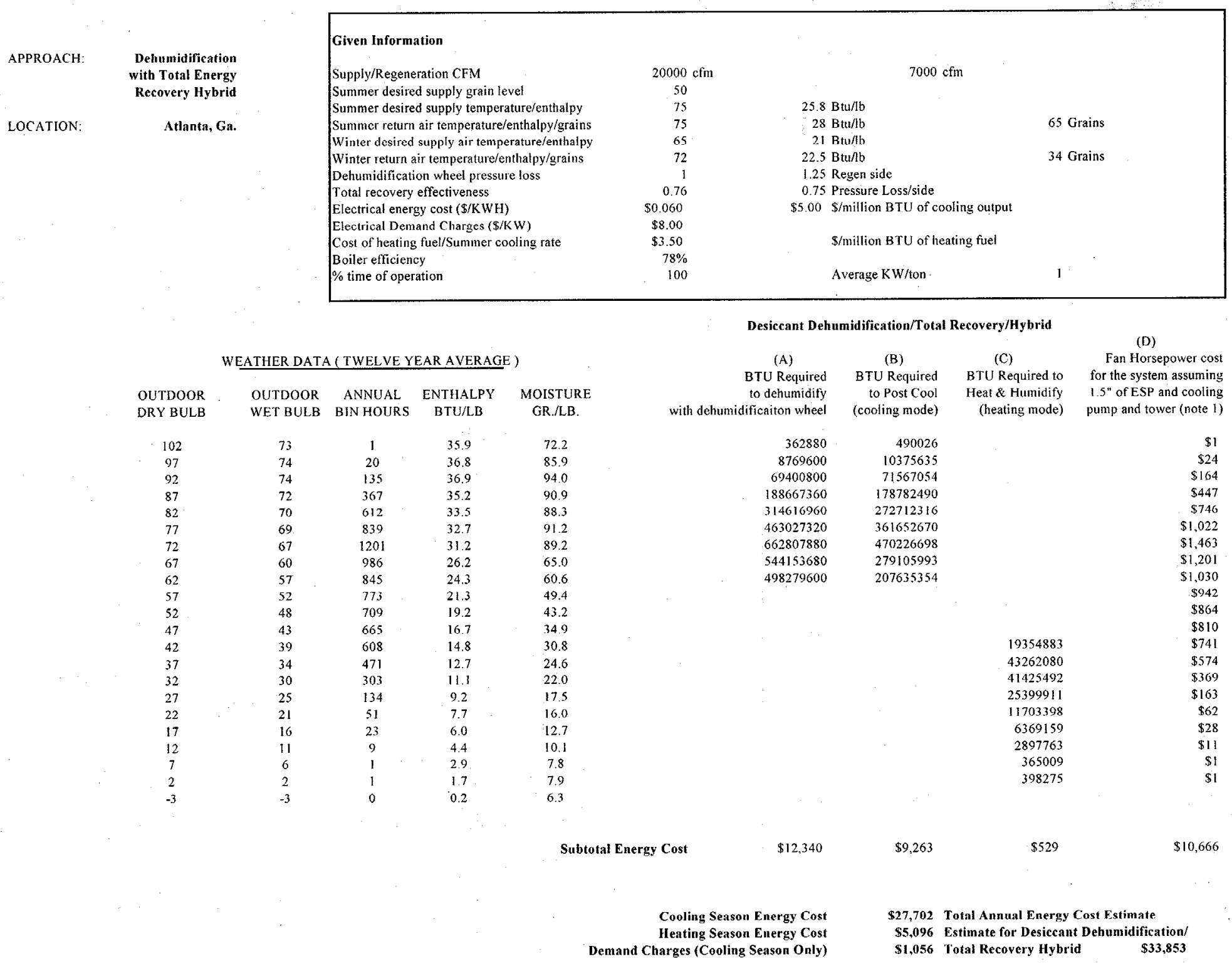

Fig. A.4. Annual operating cost estimate for the dehumidification/total energy recovery hybrid approach, modified to reflect the performance of the SEMCO $1 \mathrm{M}$ wheel. 


\begin{tabular}{|c|c|c|c|c|c|}
\hline (E) & (F) & (G) & (H) & (I) & (J) \\
\hline Humidity Grains & Temperature & Enthalpy & Temperature Leaving & Humidity Leaving & Regeneration \\
\hline Entering DH & Entering DH & Entering DH & the Dehumidification & the Dehumidification & Temperature \\
\hline Wheel & Wheel & Wheel & Wheel & Wheel & Required \\
\hline 66.7 & 81.5 & 30.0 & 97.7 & 50 & 150 \\
\hline 70.0 & 80.3 & 30.2 & 99.0 & 50 & 155 \\
\hline 72.0 & 79.1 & 30.2 & 99.5 & 50 & 160 \\
\hline 71.2 & 77.9 & 29.8 & 97.6 & 50 & 155 \\
\hline 70.6 & 76.7 & 29.4 & 95.6 & 50 & 150 \\
\hline 71.3 & 75.5 & 29.3 & 95.0 & 50 & 150 \\
\hline 70.8 & 74.3 & 28.9 & 93.1 & 50 & 145 \\
\hline 65.0 & 73.1 & 27.7 & 88.1 & 50 & 140 \\
\hline 63.9 & 71.9 & 27.2 & 86.4 & 50 & 140 \\
\hline 33.2 & 64.8 & 20.7 & & & \\
\hline 31.7 & 63.6 & 20.2 & & & \\
\hline 31.1 & 62.4 & 19.8 & & & \\
\hline 30.0 & 61.2 & 19.4 & & & \\
\hline 29.7 & 60.0 & 19.0 & & & \\
\hline 28.9 & 58.8 & 18.6 & & & \\
\hline 28.3 & 57.6 & 18.2 & & & \\
\hline 27.7 & 56.4 & 17.8 & & & \\
\hline 27.7 & 55.2 & 17.5 & & & \\
\hline
\end{tabular}

Note 1: Assumes parasitic loss for all components in the system as well as an average $0.3 \mathrm{KW} /$ ton for operating the chilled water pumps and the cooling tower.

Fig. A.4 (continued) 


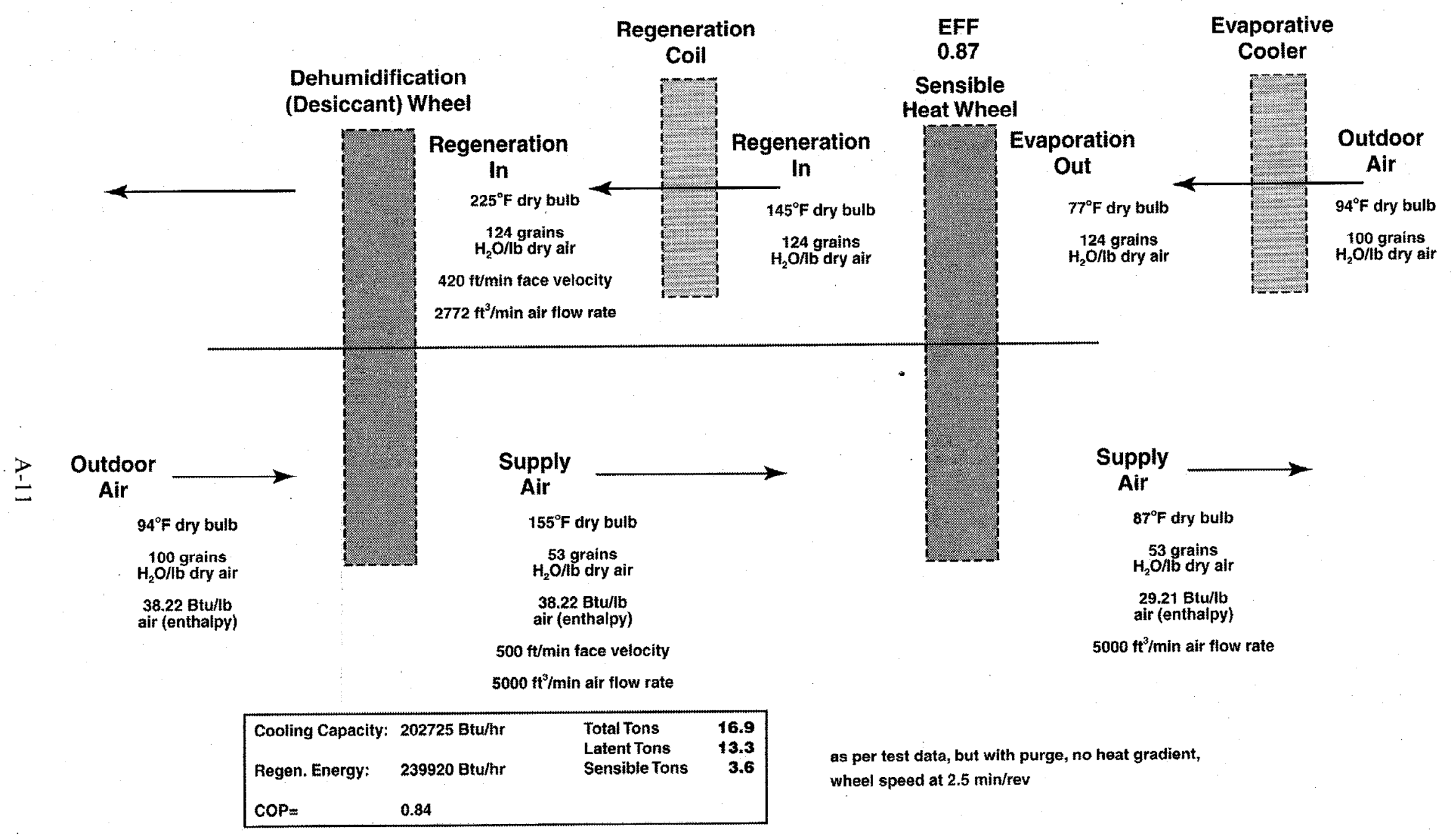

Fig. A.5. Flow schematic of typical active desiccant system performance for dry bulb BIN design condition. 


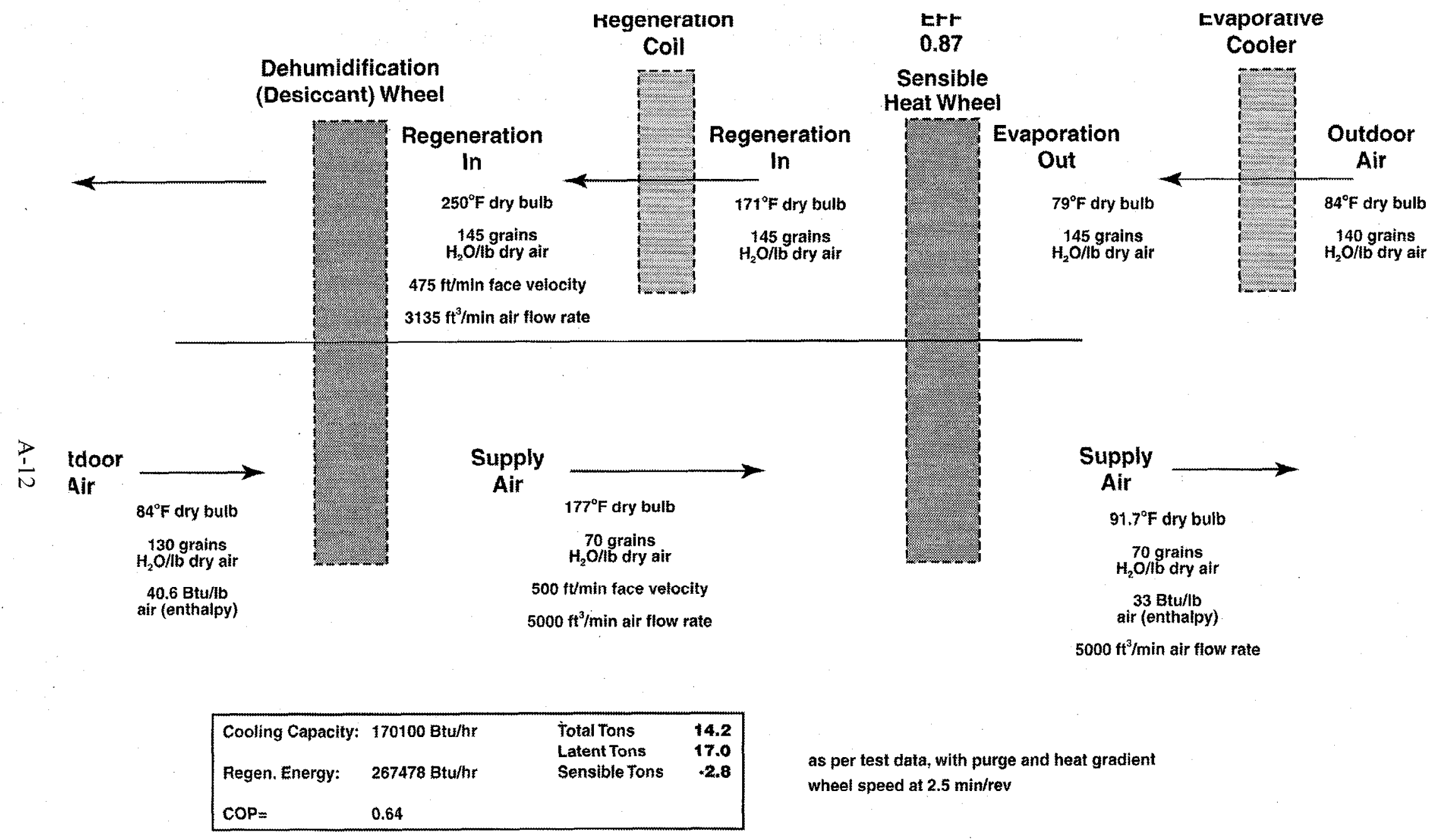

Fig. A.6. Flow schematic of typical active desiccant system performance for dew point design condition. 


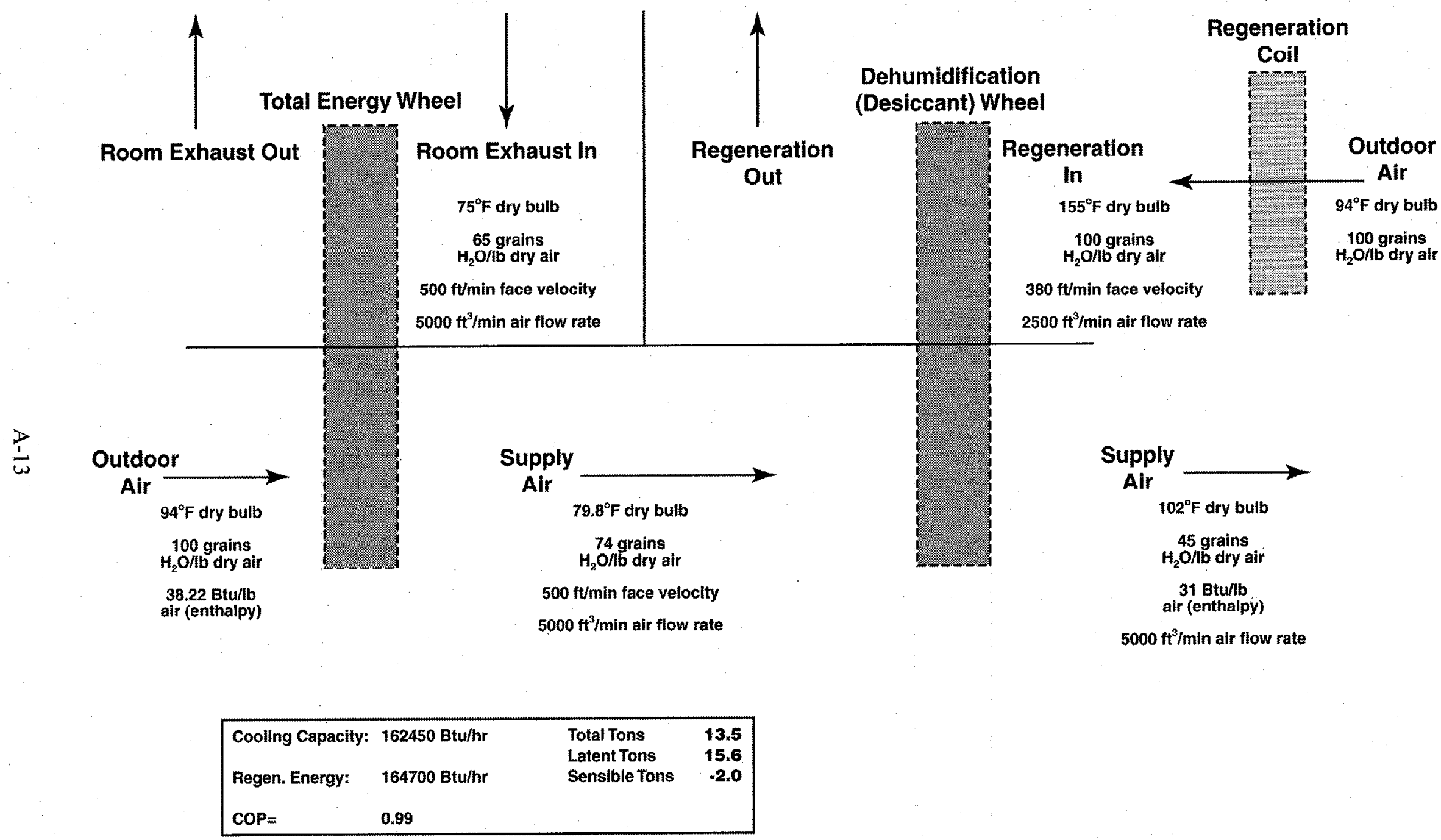

Fig. A.7. Flow schematic of dehumidification-total energy recovery system performance for dry bulb BIN design condition. 


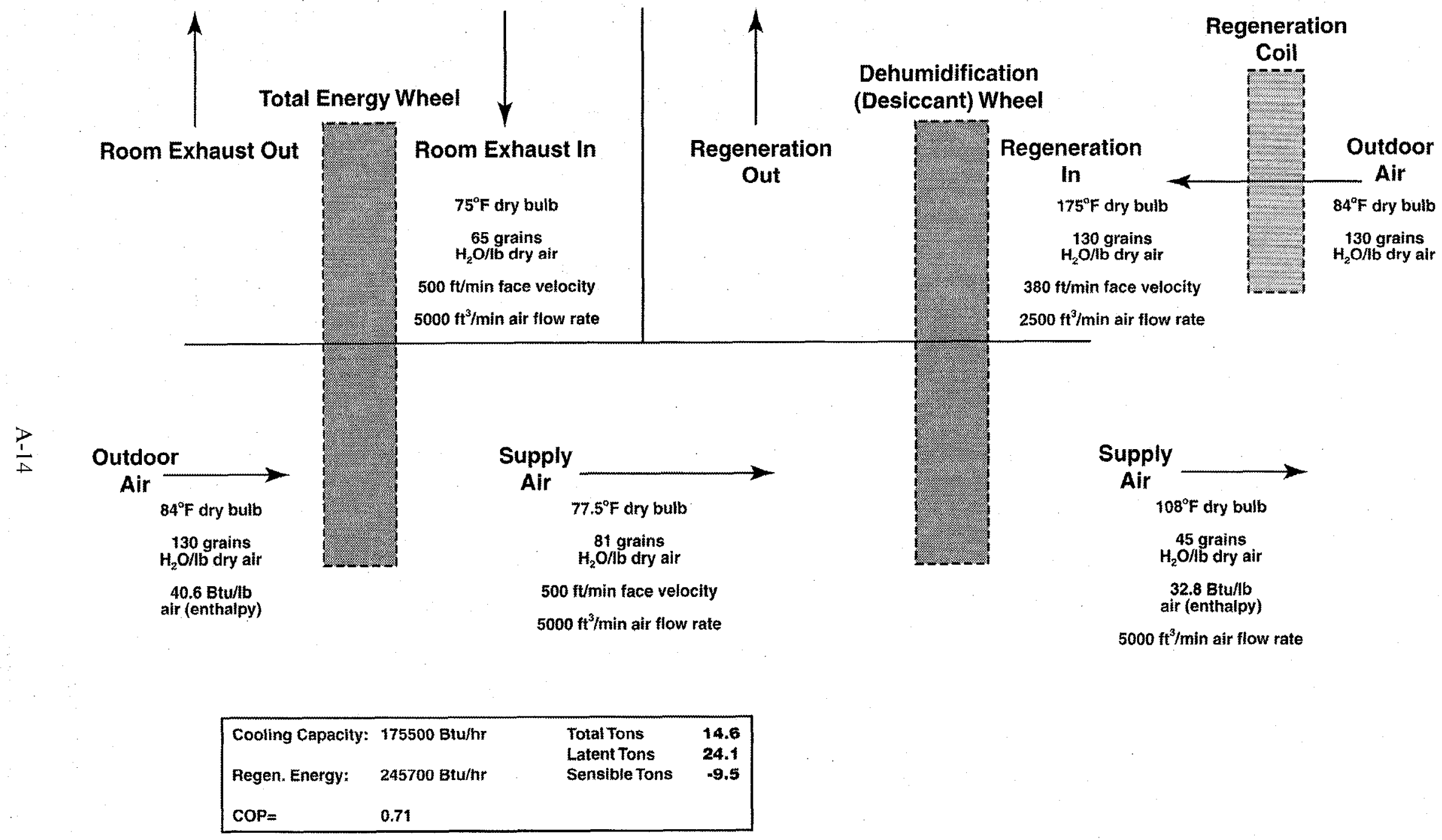

Fig. A.8. Flow schematic of dchumidification-total energy recovery system performance for dew point design condition. 


\section{INTERNAL DISTRIBUTION}

$\begin{array}{ll}\text { 1. } & \text { J. E. Christian } \\ \text { 2. } & \text { G. E. Courville } \\ \text { 3. } & \text { T. R. Curlee } \\ \text { 4. } & \text { R. C. Devault } \\ \text { 5. } & \text { P. D. Fairchild } \\ \text { 6. } & \text { M. A. Karnitz } \\ \text { 7. } & \text { C. I. Moser }\end{array}$

\author{
8-29. J. R. Sand \\ 30. A. Schaffhauser \\ 31. R. B. Shelton \\ 32. E. A. Vineyard \\ 33. Laboratory Records-RC \\ 34. Central Research Library \\ 35-36 OSTI
}

\section{EXTERNAL DISTRIBUTION}

37. Lilia A. Abron, PEER Consultants, 1460 Gulf Blvd., Apt. 1103, Clearwater, FL 33767

38. Joel Anderson, Mississippi Valley Gas Company, P.O. Box 3348, Jackson, MS 39207

39. Ren Anderson, National Renewable Energy Laboratory, 1617 Cole Blvd., Golden, CO 80401-3393

40. Frank Ballistreri, Reliant Energy-Minnegasco, P.O. Box 59038, 15th Floor, 800 LaSalle Ave., Minneapolis, MN 55459-0038

41. Douglas Bauer, Commission on Engineering and Technical Systems, National Research Council, Harris 280, 2001 Wisconsin Ave. NW, Washington, D.C., 20007

42. John C. Brady, Mechanical Engineering, ATS\&R, 8501 Golden Valley Rd., \#300, Minneapolis, MN 55427

43. Paul L. Brillhart, University of Illinois-Chicago, Energy Resources Center, 1223 SEO, 842 West Taylor St., Chicago, IL 60607-7022

44. Thom Clemens, Desicair Sales Manager, ATS, 1572 Tilco Dr., Fredrick, MD 21701

45. Susan L. Cutter, Hazards Research Laboratory, Department of Geography, University of South Carolina, Columbia, SC 20208

46. John Fischer, SEMCO, Inc., 737 Terrell Crossing, Marietta, GA 30067

47. R. Fiskum, U.S. Department of Energy, EE-42, 5E-036/Forrestal, Washington, D.C. 20585

48. P. W. Garland, UT-Battelle, LLC, 901 D St. SW, Suite 900, Washington, D.C. 20024

49. Arthur D. Hallstrom, Air Handling Systems, The Trane Company, 1500 Mercer Rd., Lexington, KY 40511

50. Lew Harriman, Mason-Grant Consulting, P.O. Box 6547, 57 South St., Portsmouth, NH 03802

51. Stephen G. Hildenbrand, Environmental Sciences Division, Oak Ridge National Laboratory, P.O. Box 2008, Oak Ridge, TN 37831-6037

52. Keith Hodge, Department of Mechanical Engineering, 210 Carpenter Engineering Bldg., P.O. Drawer ME, Mississippi State, MS 39762-5925

53. John Kelly, IGT, 1700 S. Mount Prospect Rd., Des Plaines, IL 60018-1804

54. Douglas R. Kosar, Gas Research Institute, 8600 West Bryn Mawr Ave., Chicago, IL 60631-3562

55. Tony Occhionero, American Gas Cooling Center, 400 N. Capitol St., NW, Washington, D.C. 20001

56. P. Richard Rittelmann, Burt Hill Kosar Rittelmann Associates, 400 Morgan Center, Butler, PA 160015977

57. Mike Schell, Telaire, 6489 Calle Reale, Goleta, CA 93117

58. David Simkins, Munters Corporation, P.O. Box 640, Amesbury, MA 01913

59. Steven Slayzak, Center for Buildings and Thermal Systems, National Renewable Energy Laboratory, 1617 Cole Blvd., Golden, CO 80401-3393

60. Richard S. Sweetser, EXERGY Partners Corp., 12020 Meadowville Court, Herndon, VA 20170

61. C. Michael Walton, Department of Civil Engineering, University of Texas at Austin, Austin, TX 787121076 
62. William M. Worek, University of Illinois-Chicago, Energy Resources Center, 851 S. Morgan St., 1207 SEO, Chicago, IL 60607-7054

63. Jaroslav Wurm, Director of Space Conditioning Research, IGT, 1700 S. Mount Prospect Rd., Des Plaines, IL 60018-1804 